\title{
Spectroscopic and biochemical insight into an electron-bifurcating [FeFe] hydrogenase
}

\author{
Nipa Chongdar ${ }^{1} \cdot$ Krzysztof Pawlak $^{1}$ - Olaf Rüdiger ${ }^{1} \cdot$ Edward J. Reijerse $^{1} \cdot$ Patricia Rodríguez-Maciá $^{1}$. \\ Wolfgang Lubitz ${ }^{1}$. James A. Birrell ${ }^{1} \cdot$ Hideaki Ogata ${ }^{1,2}$
}

Received: 12 October 2019 / Accepted: 21 November 2019 / Published online: 10 December 2019

(c) The Author(s) 2019

\begin{abstract}
The heterotrimeric electron-bifurcating $[\mathrm{FeFe}]$ hydrogenase $(\mathrm{HydABC})$ from Thermotoga maritima $(\mathrm{Tm})$ couples the endergonic reduction of protons $\left(\mathrm{H}^{+}\right)$by dihydronicotinamide adenine dinucleotide (NADH) $\left(\Delta G^{0} \approx 18 \mathrm{~kJ} \mathrm{~mol}^{-1}\right)$ to the exergonic reduction of $\mathrm{H}^{+}$by reduced ferredoxin $\left(\mathrm{Fd}_{\mathrm{red}}\right)\left(\Delta G^{0} \approx-16 \mathrm{~kJ} \mathrm{~mol}^{-1}\right)$. The specific mechanism by which HydABC functions is not understood. In the current study, we describe the biochemical and spectroscopic characterization of $T m \mathrm{Hyd} A B C$ recombinantly produced in Escherichia coli and artificially maturated with a synthetic diiron cofactor. We found that $T m \mathrm{HydABC}$ catalyzed the hydrogen $\left(\mathrm{H}_{2}\right)$-dependent reduction of nicotinamide adenine dinucleotide $\left(\mathrm{NAD}^{+}\right)$in the presence of oxidized ferredoxin $\left(\mathrm{Fd}_{\mathrm{ox}}\right)$ at a rate of $\approx 17 \mu \mathrm{mol} \mathrm{NADH} \mathrm{min}^{-1} \mathrm{mg}^{-1}$. Our data suggest that only one flavin is present in the enzyme and is not likely to be the site of electron bifurcation. FTIR and EPR spectroscopy, as well as FTIR spectroelectrochemistry, demonstrated that the active site for $\mathrm{H}_{2}$ conversion, the H-cluster, in TmHydABC behaves essentially the same as in prototypical [FeFe] hydrogenases, and is most likely also not the site of electron bifurcation. The implications of these results are discussed with respect to the current hypotheses on the electron bifurcation mechanism of [FeFe] hydrogenases. Overall, the results provide insight into the electron-bifurcating mechanism and present a well-defined system for further investigations of this fascinating class of [FeFe] hydrogenases.
\end{abstract}

\section{Graphic abstract}

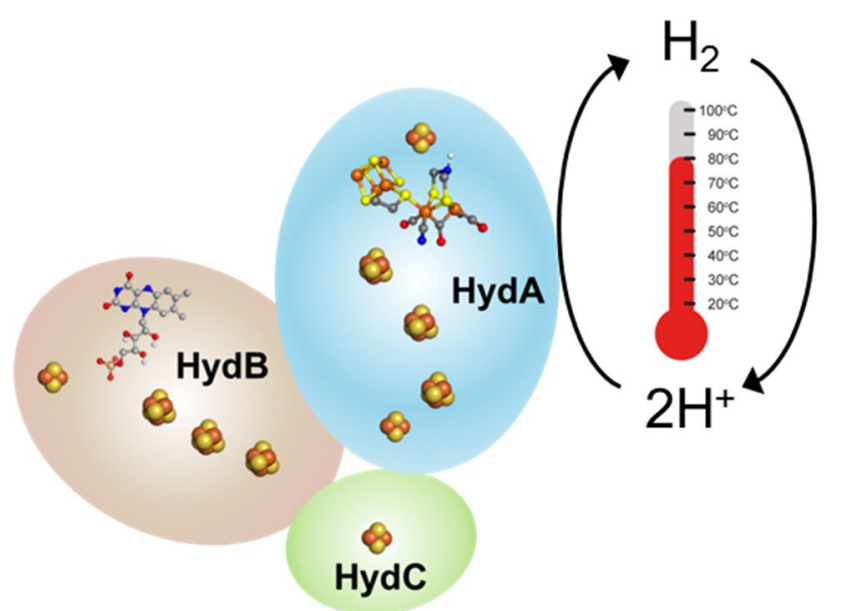

Nipa Chongdar and Krzysztof Pawlak have contributed equally to this work.

Electronic supplementary material The online version of this article (https://doi.org/10.1007/s00775-019-01747-1) contains supplementary material, which is available to authorized users.

Extended author information available on the last page of the article 
Keywords [FeFe] hydrogenase - Electron bifurcation . Spectroscopy $\cdot$ Electrochemistry $\cdot$ Ferredoxin

\section{Abbreviations}

NADH Dihydronicotinamide adenine dinucleotide

$\mathrm{NAD}^{+}$Nicotinamide adenine dinucleotide

$\mathrm{Fd}_{\mathrm{ox}} \quad$ Oxidized ferredoxin

$\mathrm{Fd}_{\text {red }} \quad$ Reduced ferredoxin

ADT 2-azapropane 1,3-dithiolate

FMN Flavin mononucleotide

FTIR Fourier transform infrared

EPR Electron paramagnetic resonance

FAD Flavin adenine dinucleotide

$\mathrm{CW} \quad$ Continuous wave

OCP Open-circuit potential

PCET Proton-coupled electron transfer

FBEB Flavin-based electron bifurcation

\section{Introduction}

[FeFe] hydrogenases catalyze the reversible interconversion of protons $\left(\mathrm{H}^{+}\right)$and electrons to hydrogen $\left(\mathrm{H}_{2}\right)$ at very high rates, with negligible energy waste [1-3]. Their active center, the $\mathrm{H}$-cluster, consists of a unique [2Fe] cluster $\left([2 \mathrm{Fe}]_{\mathrm{H}}\right)$ tethered covalently by a cysteine thiolate to a standard $[4 \mathrm{Fe}-4 \mathrm{~S}]$ cluster $\left([4 \mathrm{Fe}-4 \mathrm{~S}]_{\mathrm{H}}\right)(\mathrm{Fig} .1 \mathrm{a})[4,5]$. The Fe ions in the $[2 \mathrm{Fe}]_{\mathrm{H}}$ subsite are coordinated by $\mathrm{CO}$ and $\mathrm{CN}^{-}$ligands and also by a bidentate 2-azapropane 1,3-dithiolate (ADT) ligand that bridges the two irons of $[2 \mathrm{Fe}]_{\mathrm{H}}$ (Fig. 1a). The H-cluster is buried inside a highly optimized protein scaffold, which tunes its catalytic efficiency and provides pathways for the transport of protons, electrons, and gases (the substrate $\mathrm{H}_{2}$ as well as inhibitors such as $\mathrm{CO}$ and $\left.\mathrm{O}_{2}\right)[6]$.

During $\mathrm{H}_{2}$ conversion, the $\mathrm{H}$-cluster passes through several redox states [1]. In the active oxidized state $\left(\mathrm{H}_{\mathrm{ox}}\right)$, the $[2 \mathrm{Fe}]_{\mathrm{H}}$ subcluster is in a mixed valent $[\mathrm{Fe}(\mathrm{I}) \mathrm{Fe}(\mathrm{II})]$ state, and the $[4 \mathrm{Fe}-4 \mathrm{~S}]_{\mathrm{H}}$ subsite is oxidized $(2+)$. One-electron reduction of the $[4 \mathrm{Fe}-4 \mathrm{~S}]_{\mathrm{H}}$ subsite forms the $\mathrm{H}_{\text {red }}$ state [7]. Protonation of the ADT in the $\mathrm{H}_{\text {red }}$ state is coupled to electron transfer from the reduced $[4 \mathrm{Fe}-4 \mathrm{~S}]_{\mathrm{H}}$ to the $[2 \mathrm{Fe}]$ cluster, yielding the $\mathrm{H}_{\text {red }} \mathrm{H}^{+}$state [8]. A second electron reduction forms the most reduced state, $\mathrm{H}_{\text {sred }} \mathrm{H}^{+}\left([4 \mathrm{Fe}-4 \mathrm{~S}]^{1+}-[\mathrm{Fe}(\mathrm{I})\right.$ $\mathrm{Fe}(\mathrm{I})]$ ) [9]. Rearrangement of the $\mathrm{H}_{\text {sred }} \mathrm{H}^{+}$state gives the $\mathrm{H}_{\text {hyd }}$ state, where a terminal hydride is bound to the [2Fe] subsite with an $\mathrm{Fe}(\mathrm{II}) \mathrm{Fe}(\mathrm{II})$ configuration and $[4 \mathrm{Fe}-4 \mathrm{~S}]_{\mathrm{H}}$ remains reduced $[10,11]$. Protonation of $\mathrm{H}_{\text {hyd }}$ leads to $\mathrm{H}_{2}$ production and regeneration of the $\mathrm{H}_{\mathrm{ox}}$ state.

Based on amino acid sequence phylogeny, the $[\mathrm{FeFe}]$ hydrogenases have been classified into three major groups: (I) prototypical and electron-bifurcating; (II) ancestral; and (III) sensory [12]. The physiological roles of the prototypical
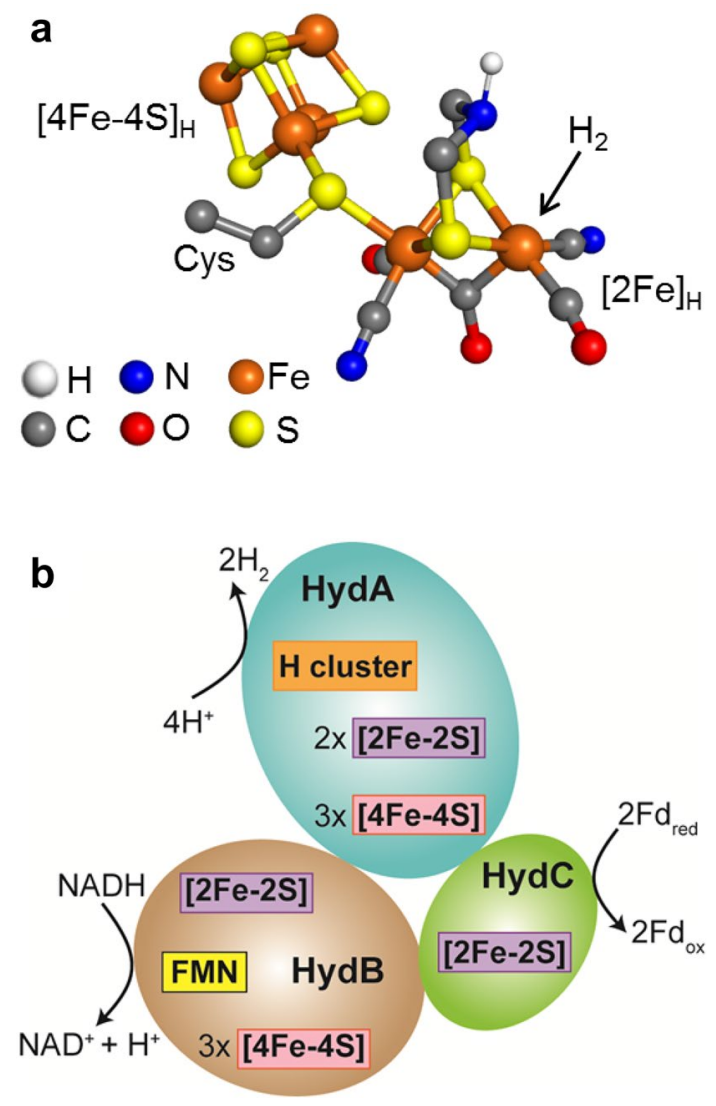

Fig. 1 a Ball and stick representation of the structure of the H-cluster. The figure was created in Pymol using PDB file 4XDC. b Schematic diagram showing the three subunits of TmHydABC. The cofactors bound to the protein were predicted from amino acid sequence analysis [26]. The arrangement of subunits and the designated reactions occurring at each subunit are based on the proposition by Buckel and Thauer [23]

[FeFe] hydrogenases are far better understood than the other classes. While the prototypical $[\mathrm{FeFe}]$ hydrogenases use ferredoxin or cytochrome as their sole redox partner, the electron-bifurcating $[\mathrm{FeFe}]$ hydrogenases use both ferredoxin $(\mathrm{Fd})$ and dihydronicotinamide adenine dinucleotide (NADH) simultaneously during $\mathrm{H}_{2}$ evolution [13-16].

Electron bifurcation is a process, whereby an endergonic redox reaction and an exergonic redox reaction are directly coupled, and is an alternative energy conservation mechanism to the well-known chemiosmotic coupling mechanism $[16,17]$. First described by Peter Mitchell in the Q-cycle of mitochondrial complex III [18], it was only about a decade ago that the involvement of electron bifurcation in the metabolism of anaerobic microorganisms was discovered [19]. Subsequent investigations showed that in a variety of reactions in anaerobic metabolism, electron bifurcation is involved [20], among them: coupling of the endergonic oxidation of NADH $\left(E_{0}{ }^{\prime}=-320 \mathrm{mV}\right)$ to the exergonic oxidation of reduced ferredoxin $\left(\mathrm{Fd}_{\text {red }}\right)\left(E_{0}{ }^{\prime} \approx-450 \mathrm{mV}\right)$ to reduce 
$\mathrm{H}^{+}$to $\mathrm{H}_{2}\left(E_{0}{ }^{\prime}=-420 \mathrm{mV}\right)$. The overall reaction is the recycling of NADH, generated by the oxidation of sugars, driven by $\mathrm{Fd}_{\text {red }}$ oxidation and can be described in full as $[14,16$, 21-23]:

$\mathrm{NADH}+2 \mathrm{Fd}_{\mathrm{red}}+3 \mathrm{H}^{+} \rightleftharpoons \mathrm{NAD}^{+}+2 \mathrm{Fd}_{\mathrm{ox}}+2 \mathrm{H}_{2}$

This reaction is essential in many organisms as various metabolic steps only yield enough energy to reduce nicotinamide adenine dinucleotide $\left(\mathrm{NAD}^{+}\right)$, but $\mathrm{NADH}$ is not capable of reducing protons. Thus, by coupling NADH oxidation to ferredoxin oxidation, protons can be used as a terminal electron acceptor [20, 21].

Electron-bifurcating [FeFe] hydrogenases are widely found in the genomes of anaerobic bacteria belonging to the phyla of Bacteroidetes, Firmicutes, Spirochaetes, Thermotogae, and Fusobacteria [12]. Bacteria belonging to Bacteroidetes and Firmicutes phyla are commonly found in mammalian guts, and as $\mathrm{H}_{2}$ is an abundant metabolite in the gastrointestinal tract, hydrogenases found in the abovementioned organisms play an important role in colonic $\mathrm{H}_{2}$ metabolism [24]. Interestingly, in a recent bioinformatics study, it has been shown that a wide variety of hydrogenases found in the bacteria of the human gut belong to the electron-bifurcating class [25]. Therefore, understanding the metabolism of these organisms may also be important for medical applications.

Electron-bifurcating $[\mathrm{FeFe}]$ hydrogenases have been characterized from a number of organisms; however, the main focus of all these studies were their biochemical properties [14, 21, 27-29]. Even though the electron-bifurcating $[\mathrm{FeFe}]$ hydrogenase from Thermotoga maritima $(\mathrm{Tm})$ has been spectroscopically characterized [26, 30], ambiguities in the understanding of its biophysical properties still persist. In this work, based on the previous efforts of recombinant expression and artificial maturation of $[\mathrm{FeFe}]$ hydrogenases, we have developed a recombinant system to overexpress $T m \mathrm{HydABC}$ in $E$. coli followed by its artificial maturation in vitro. This system allows the generation of high yields of pure enzyme, making it possible to perform a complete spectroscopic analysis to study in detail the electron-bifurcating mechanism of $T m \mathrm{HydABC}$ [FeFe] hydrogenase.

The genome of the hyperthermophilic bacterium, $T$. maritima, contains genes encoding a prototypical, a sensory, and an electron-bifurcating type [FeFe] hydrogenase $[14,21,31]$. Previous biochemical studies showed that the electron-bifurcating $[\mathrm{FeFe}]$ hydrogenase, $T m \mathrm{HydABC}$, is the key enzyme responsible for $\mathrm{H}_{2}$ production in T. maritima [14]. The electron-bifurcating [FeFe] hydrogenase from T. maritima is a trimeric protein composed of TmHydA, TmHydB, and TmHydC (Fig. 1b) [26]. The largest subunit, TmHydA, harbors the H-cluster along with three additional $[4 \mathrm{Fe}-4 \mathrm{~S}]$ and two $[2 \mathrm{Fe}-2 \mathrm{~S}]$ clusters. TmHydB is the second largest subunit and consists of three $[4 \mathrm{Fe}-4 \mathrm{~S}]$ clusters, one [2Fe-2S] cluster, a flavin mononucleotide (FMN) binding domain, and an NADH-binding motif. TmHydC is the smallest of the three subunits and contains only one $[2 \mathrm{Fe}-2 \mathrm{~S}]$ cluster [32, 33].

The mechanistic study of prototypical $[\mathrm{FeFe}]$ hydrogenases has greatly benefited from the discovery of 'artificial maturation', whereby heterologously produced apo-proteins, that is the protein containing the $[4 \mathrm{Fe}-4 \mathrm{~S}]_{\mathrm{H}}$ sub cluster but lacking $[2 \mathrm{Fe}]_{\mathrm{H}}$, have been reconstituted using chemically synthesized precursor complexes [34, 35]. Here, we have expanded the repertoire of hydrogenases to which artificial maturation can be applied by employing it to produce the trimeric $T m \mathrm{HydABC}$ and also the catalytic subunit $T m \mathrm{HydA}$. Subsequently, we have performed biochemical assays with the resulting hydrogenase as well as a full spectroscopic characterization of the H-cluster. The results reveal insight into the bifurcation mechanism and even more importantly provide the basis for further investigation of this unresolved phenomenon.

\section{Materials and methods}

\section{Activity assays}

Hydrogen oxidation activity of $T m \mathrm{HydABC}$ and $T m \mathrm{HydA}$ was measured by following the reduction of $1 \mathrm{mM}$ benzyl viologen (at $600 \mathrm{~nm}, \varepsilon_{600}=7.8 \mathrm{mM}^{-1} \mathrm{~cm}^{-1}$ ) in $200 \mathrm{mM}$ $\mathrm{H}_{2}$-saturated potassium phosphate buffer, $\mathrm{pH} 8$. The reactions were performed at various temperatures $\left(30-80{ }^{\circ} \mathrm{C}\right)$ by the addition of $25-50 \mathrm{ng}$ protein to $1 \mathrm{~mL}$ of the abovementioned reaction buffer in $1.5 \mathrm{~mL}$ plastic cuvettes and the change in absorbance was measured using an Ocean Optics DH-mini UV-Vis-NIR light source and a USB2000+ XR1ES detector, operated by the SpectraSuite ${ }^{\mathrm{TM}}$ software. The desired reaction temperatures were achieved using a temperature controlled cuvette holder (CUV-QPOD-2E-ABSKIT, Ocean Optics). All values are the average of three measurements after subtracting the value of the blank measurement. The other details are described in the figure captions.

The $\mathrm{NAD}^{+}$and ferredoxin-dependent $\mathrm{H}_{2}$ oxidation assay of $\mathrm{TmHydABC}$ was performed at $70{ }^{\circ} \mathrm{C}$ by addition of $300-600 \mathrm{ng}$ of the protein to $1 \mathrm{~mL}$ of $\mathrm{H}_{2}$ saturated $200 \mathrm{mM}$ potassium phosphate buffer, $\mathrm{pH}$ 8. The formation of NADH (monitored at $340 \mathrm{~nm}, \varepsilon=6.2 \mathrm{mM}^{-1} \mathrm{~cm}^{-1}$ ) and reduction of ferredoxin (monitored at $430 \mathrm{~nm}, \varepsilon=12 \mathrm{mM}^{-1} \mathrm{~cm}^{-1}$ ) were determined from the change in absorbance measured using a spectrophotometer.

To determine the methyl viologen dependent hydrogen production, $250-500 \mathrm{ng}$ of protein was added to $10 \mathrm{mM}$ methyl viologen reduced with $100 \mathrm{mM}$ sodium dithionite 
(NaDT) in $200 \mathrm{mM}$ potassium phosphate buffer $\mathrm{pH} 8$ in $2.5 \mathrm{~mL}$ plastic tubes with rubber stoppers. The reaction mixture was purged with argon for 5 min and incubated at the desired reaction temperature for $10 \mathrm{~min}$ before $0.5 \mathrm{~mL}$ of the headspace gas was extracted for analysis. The head space gas was then analyzed by gas chromatography. Hydrogen content was quantified by comparison with a $100 \% \mathrm{H}_{2}$ standard. All values are the average of three measurements after subtracting the value of a blank measurement.

\section{Electrochemistry}

Protein film electrochemistry experiments were performed using a gas-tight three electrode setup inside an anaerobic glovebox (MBraun) filled with $\mathrm{N}_{2}$. The cell temperature was controlled by a water-jacket system. A pyrolytic graphite edge disk $\left(0.03 \mathrm{~cm}^{2}\right.$, Momentive Materials $)$ was used as a working electrode and a Pt wire as a counter electrode. The reference electrode (saturated calomel electrode-SCE) was placed in a side arm (at room temperature), connected to the main cell compartment by a Luggin capillary. Electrochemical experiments were controlled by a VersaStat 4 potentiostat (Princeton Applied Research). The electrochemical cell was filled with a buffer mixture of MES, HEPES, TAPS, CHES, and sodium acetate adjusted to $\mathrm{pH}$ 5, 6, 7, 8, 9, and 10 . Cyclic voltammetry was performed under $100 \% \mathrm{H}_{2}$ with a $2000 \mathrm{rpm}$ rotation rate (Princeton Applied Research model 636A). The potentials were converted to the standard hydrogen electrode (SHE) using a conversion of $+241 \mathrm{mV}$ from SCE.

\section{FTIR spectroscopy}

FTIR spectroscopy was performed using home-built watercooled sample holders accommodated in a Bruker Vertex v80 spectrometer. Samples $(10 \mu \mathrm{L})$ were placed between two $\mathrm{CaF}_{2}$ (Korth Kristalle, Altenholz) windows, separated by a $50 \mu \mathrm{m}$ Teflon spacer, and sealed with rubber rings. The temperature of the sample holder was maintained using a water circulator system (Huber, Offenburg). The spectrometer was equipped with a liquid nitrogen cooled fast mercury cadmium telluride photovoltaic (D317/B) detector. Spectra were collected at room temperature in double-sided, forward-backward mode with a $2 \mathrm{~cm}^{-1}$ resolution and $20 \mathrm{kHz}$ scanner velocity.

\section{FTIR spectroelectrochemistry}

Spectroelectrochemical experiments were performed using a home-built electrochemical cell according to the design described by Moss et al. $[1,36]$. Protein samples $(1-1.5 \mathrm{mM})$ containing $0.5 \mathrm{mM}$ of the redox mediators benzyl viologen $\left(E_{\mathrm{m}}=-358 \mathrm{mV}\right)$ and methyl viologen $\left(E_{\mathrm{m}}=-449 \mathrm{mV}\right)$ were loaded between two $\mathrm{CaF}_{2}$ (Korth Kristalle, Altenholz) windows on a gold mesh working electrode (approximately $20 \mu \mathrm{m}$ thick) in electrical contact with a platinum counter electrode. $\mathrm{An} \mathrm{Ag} / \mathrm{AgCl}(1 \mathrm{M} \mathrm{KCl})$ electrode was used as a reference and was calibrated before and after the measurement with (hydroxymethyl)ferrocene $\left(E_{m}=+436 \mathrm{mV}\right)$. In the titrations, the potential was controlled by an Autolab PGSTAT101 potentiostat controlled by the Nova software.

The measurements were performed using a Bruker IFS 66v/S FTIR spectrometer equipped with a mercury cadmium telluride photovoltaic detector in double-sided, forward-backward mode with $2 \mathrm{~cm}^{-1}$ resolution, and $20 \mathrm{kHz}$ scanner velocity. The temperature $\left(15^{\circ} \mathrm{C}\right)$ was maintained by a water circulator (Huber). Spectra were collected after 40 min incubation time at each applied potential.

\section{EPR spectroscopy}

X-band EPR spectra were recorded on a Bruker ELEXSYS E500 CW X-band EPR spectrometer. The temperature of the samples was controlled using an Oxford Instruments ESR900 helium flow cryostat connected to an ITC503 temperature controller. The measurement parameters were: microwave frequency $9.64 \mathrm{GHz}$, time constant $81.92 \mathrm{~ms}$, conversion time $81.92 \mathrm{~ms}$, and modulation frequency $100 \mathrm{kHz}$. The microwave power and temperature were varied between measurements and are indicated in the figure legends.

The EPR samples $(200 \mu \mathrm{L})$ were transferred anaerobically to $4 \mathrm{~mm}$ (o.d.) quartz EPR tubes and frozen in liquid nitrogen. All spectra were analyzed with home-written scripts in MATLAB. Spectral simulations were performed using the EasySpin package [37]. Spin quantification was achieved by comparison with a $1 \mathrm{mM} \mathrm{CuSO}_{4}, 10 \mathrm{mM}$ EDTA standard.

\section{Results}

\section{Characterization of apo-TmHydABC and apo-TmHydA}

The apo-TmHydABC and apo-TmHydA were produced recombinantly in $E$. coli (details of construct preparation, heterologous expression, and purification are provided in the Supplementary Information). Iron quantification of apo-TmHydABC and apo-TmHydA indicated the presence of $35 \pm 2$ and $19 \pm 1$ moles of iron per mole of protein, respectively, in good agreement with the expected values (36 for apo-TmHydABC and 20 for apo-TmHydA) based on the number of iron-sulfur $(\mathrm{FeS})$ clusters, and on the previously reported data on $\mathrm{TmHydABC}$ and $\mathrm{TmHydA}$ isolated from the native organism [26]. Flavin quantification gave $0.2 \pm 0.05$ moles of FMN per mole of protein. Inclusion of 
riboflavin during protein overexpression did not enhance the FMN content. Thus, it is likely that the majority of the FMN is lost during purification, as has been demonstrated also for native TmHydABC [26].

Apo-TmHydABC and apo-TmHydA were analyzed using $\mathrm{UV}-\mathrm{Vis}$ and continuous wave $(\mathrm{CW})$ electron paramagnetic resonance (EPR) spectroscopy (Figure S5). In both cases, the UV-Vis spectrum showed broad bands in the range from 300 to $600 \mathrm{~nm}$ (Figure S5A) typical for [2Fe-2S] and [4Fe-4S] clusters. EPR spectra from apo-TmHydABC and apo- $T m$ HydA reduced with sodium dithionite are shown in Figure S5B. The EPR spectrum of apo-TmHydABC at $40 \mathrm{~K}$ is similar to that observed with the reduced native protein and has $g$ values and relaxation properties consistent with [2Fe-2S] clusters (Figure S5B, upper panel) [26]. The EPR spectrum of apo-TmHydABC at $10 \mathrm{~K}$ appears to be more complex than that at $40 \mathrm{~K}$, with the broadening of the feature at $g \approx 2.02$ and appearance of a new feature at $g \approx 1.88$ (Figure $\mathrm{S} 5 \mathrm{~B}$, upper panel). This phenomenon was also observed in the native protein and was attributed to the weak dipolar interactions between the clusters [26]. The EPR spectrum of apo-TmHydA is very similar to the apo-TmHydABC EPR spectrum at $40 \mathrm{~K}$ (Figure S5B, lower panel). Interestingly, at $10 \mathrm{~K}$ the EPR spectrum of $T m \mathrm{HydA}$ does not show such a large contribution from the broad feature as apoTmHydABC. Nevertheless, it can be concluded that apoTmHydABC and apo-TmHydA contain both [2Fe-2S] and [4Fe-4S] clusters essentially identical to that of the proteins purified from the native organism.

\section{Activity assays with artificial partners}

The apo-TmHydABC and apo-TmHydA were artificially maturated using the previously published in vitro method (see Supplementary Text 3 for details) to generate the holoenzymes $[34,35]$. Activity assays with holo-TmHydABC and holo-TmHydA in solution were performed to obtain the rates of $\mathrm{H}_{2}$ oxidation coupled to benzyl viologen reduction and $\mathrm{H}_{2}$ production coupled to methyl viologen oxidation. At $30^{\circ} \mathrm{C}, T m \mathrm{HydABC}$ and $\mathrm{Tm} \mathrm{HydA}$ oxidized $\mathrm{H}_{2}$ at a rate of $\approx 500 \mathrm{U} \mathrm{mg}^{-1}$ and $\approx 800 \mathrm{U} \mathrm{mg}^{-1}$, respectively ( $1 \mathrm{U}=1 \mu \mathrm{mol} \mathrm{min}{ }^{-1}$ ) (Fig. 2a). The $\mathrm{H}_{2}$ production activities of $T m \mathrm{HydABC}$ and $T m \mathrm{HydA}$ at $37{ }^{\circ} \mathrm{C}$ were found to be $\approx 270 \mathrm{U} \mathrm{mg}^{-1}$ and $\approx 150 \mathrm{U} \mathrm{mg}^{-1}$, respectively (Fig. 2b). While both activities increased with temperature, a stronger effect was found for $\mathrm{H}_{2}$ oxidation (Fig. 2). Compared to TmHydABC isolated from the native organism the artificially maturated protein showed significantly higher activity [38]. This could be related to a higher conversion of the COinhibited state $\mathrm{H}_{\mathrm{ox}}-\mathrm{CO}$ to the active states in the artificially maturated protein, while in the native organism, a larger fraction of the isolated protein is in the inactive $\mathrm{H}_{\mathrm{ox}}-\mathrm{CO}$ state.

\section{Catalytic activity using protein film electrochemistry}

The catalytic activity of $T m \mathrm{HydABC}$ and $T m \mathrm{HydA}$ was also measured electrochemically by adsorbing the enzymes on pyrolytic graphite electrodes (Fig. 3). Due to protein
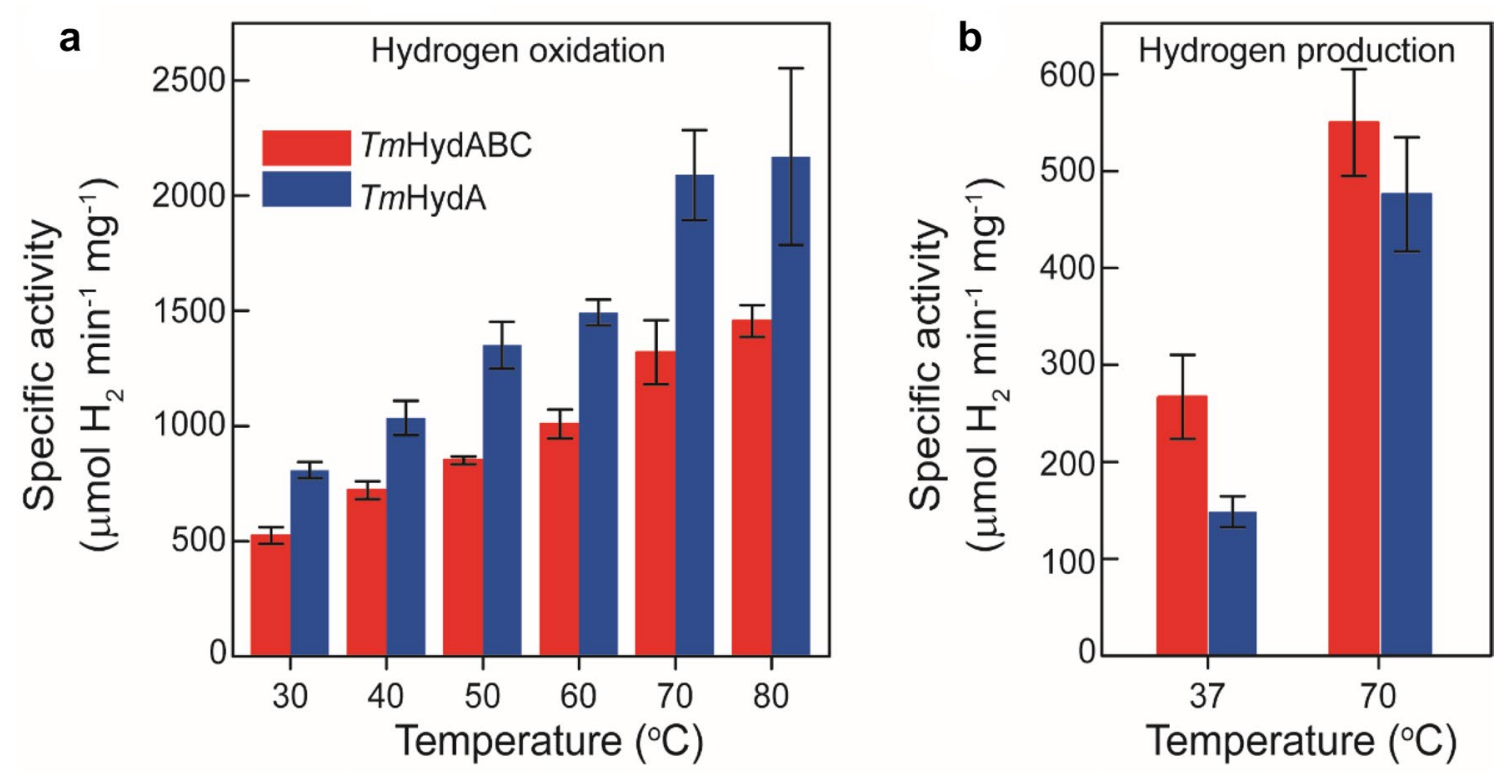

Fig. 2 Activity assays of artificially maturated $T m \mathrm{HydABC}$ and TmHydA. a Temperature dependence of $\mathrm{H}_{2}$ oxidation of both proteins was measured in the range from 30 to $80{ }^{\circ} \mathrm{C}$ with benzyl viologen

as the electron acceptor. b $\mathrm{H}_{2}$ production activity of TmHydABC and $\mathrm{Tm}$ HydA was measured at $37^{\circ} \mathrm{C}$ and $70{ }^{\circ} \mathrm{C}$ with reduced methyl viologen as electron donor 


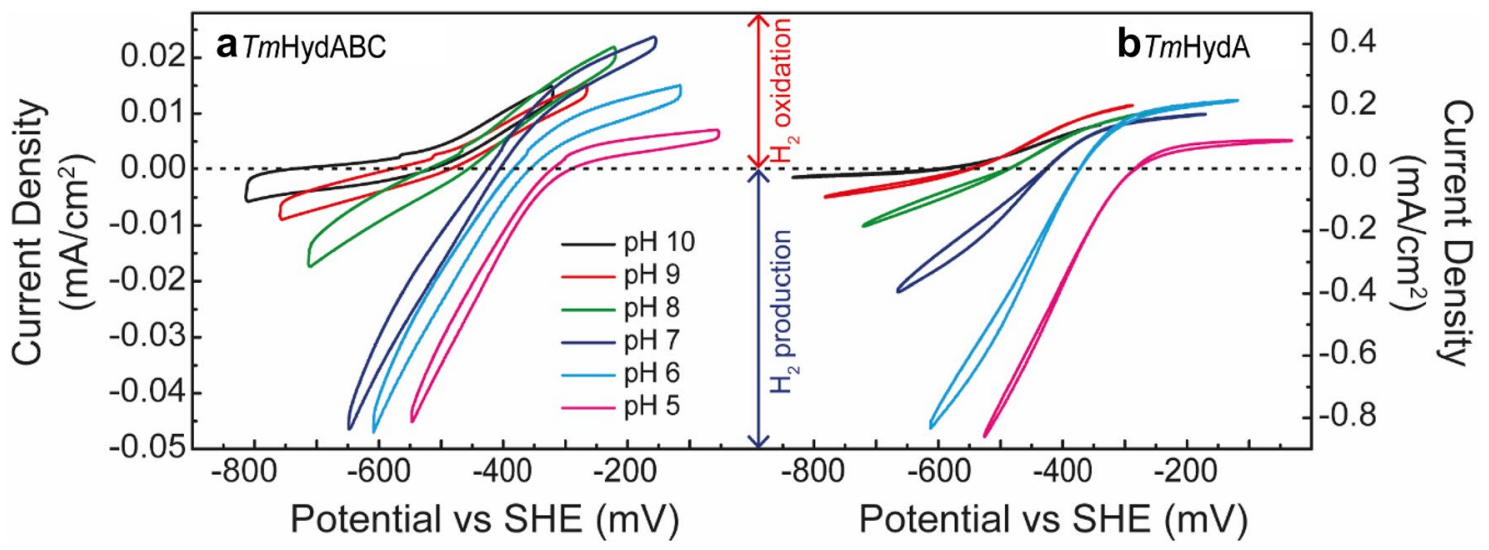

Fig. 3 Cyclic voltammetry of TmHydABC (a) and TmHydA (b) adsorbed onto the surface of a pyrolytic graphite electrode. The applied potential was swept from open-circuit potential to $250 \mathrm{mV}$

desorption at increased temperatures, the maximum temperature that could be used was $35^{\circ} \mathrm{C}$. Under these conditions reasonably stable films were formed such that individual voltammograms could be measured over a range of different $\mathrm{pH}$ values. From these measurements, it was clear that higher current densities are achieved with TmHydA (up to $-0.9 \mathrm{~mA} \mathrm{~cm}^{-2}$ for $\mathrm{H}^{+}$reduction) (Fig. 3b) than TmHydABC (up to $-0.045 \mathrm{~mA} \mathrm{~cm}^{-2}$ for $\mathrm{H}^{+}$reduction) (Fig. 3a), but otherwise, the two enzymes behaved in a similar fashion showing a bias towards $\mathrm{H}^{+}$reduction at neutral to low $\mathrm{pH}$. The difference in current densities between TmHydA and TmHydABC could be related to the larger size of TmHydABC (160 kDa) compared to TmHydA (72 kDa), which may lead to higher electroactive coverage (surface concentration of the electroactive enzyme) for $T m H y d A$, as more enzymes can fit into the same surface area. The oligomeric nature of the enzyme can also influence the electroactive coverage: TmHydABC forms a tetramer of trimers in solution (around $700 \mathrm{kDa}$ ), while $T m \mathrm{HydA}$ behaves as a monomer or dimer (Figures S2 and S3). Protein film electrochemistry reveals that for both $T m \mathrm{HydABC}$ and $T m \mathrm{HydA}$, the $\mathrm{H}^{+}$reduction current is strongly $\mathrm{pH}$ dependent, dominating over $\mathrm{H}_{2}$ oxidation at $\mathrm{pH}$ values below 8 , while the $\mathrm{H}_{2}$ oxidation current is relatively $\mathrm{pH}$ independent (Fig. 3). Both enzymes show reversible electrochemical behavior with essentially no over-potential requirement in either direction (Fig. 3). The behavior of TmHydA is reminiscent of that from Clostridium pasteurianum and Clostridium acetobutylicum $[\mathrm{FeFe}]$ hydrogenases both of which show a bias towards $\mathrm{H}^{+}$reduction at neutral $\mathrm{pH}[9,39]$.

\section{Catalytic activity using physiological partners}

The TmHydABC enzyme isolated from the native organism was unable to produce $\mathrm{H}_{2}$ with reduced ferredoxin as more positive and then to $250 \mathrm{mV}$ more negative, to compare the catalytic currents at the same overpotential. The measurements were performed at $35^{\circ} \mathrm{C}$ under $100 \% \mathrm{H}_{2}$

the sole electron donor [14]. However, when reduced ferredoxin and NADH were added together as electron donors, TmHydABC could evolve $\mathrm{H}_{2}$ [14]. Thus, TmHydABC acts as an electron-confurcating (reverse of bifurcation) hydrogenase, which converges electrons from two different sources to reduce protons to $\mathrm{H}_{2}[14,23]$. To check if the recombinantly produced and artificially maturated $T m \mathrm{HydABC}$ is able to perform electron bifurcation, we followed the reverse reaction, i.e., we monitored $\mathrm{H}_{2}$ oxidation coupled to reduction of $\mathrm{NAD}^{+}$and ferredoxin. The ferredoxin $(\mathrm{TmFd} 1)$ used for this assay is a single $[4 \mathrm{Fe}-4 \mathrm{~S}]$ cluster containing ferredoxin from T. maritima (details of its purification and characterization are provided in the Supplementary Text 4 and Figure S8). TmHydABC was not able to reduce $T m \mathrm{Fd} 1$ in an $\mathrm{H}_{2}$-saturated assay mixture containing FMN but lacking $\mathrm{NAD}^{+}$(indicated by the unchanged absorbance intensity at $430 \mathrm{~nm}$ ) (Fig. 4a). As soon as NAD ${ }^{+}$was added to the assay, a decrease in the absorbance at $430 \mathrm{~nm}$ was observed, indicating reduction of $T m \mathrm{Fd} 1$ (Fig. 4a). Concomitantly, NADH production was detected by an increase of the absorbance at $340 \mathrm{~nm}$ (Fig. 4a). The changes in the absorbance intensities at $340 \mathrm{~nm}$ and $430 \mathrm{~nm}$ were not observed in the absence of TmHydABC, indicating that the $\mathrm{H}_{2}$-dependent reduction of $\mathrm{NAD}^{+}$and $T m \mathrm{Fd} 1$ is indeed catalyzed by $T m \mathrm{HydABC}$.

The above observation was also confirmed by EPR spectroscopy (Fig. 4b). The reaction mixture containing NAD ${ }^{+}$ and $T m F d 1$, but lacking TmHydABC, does not show EPR signals corresponding to the reduced $[4 \mathrm{Fe}-4 \mathrm{~S}]$ cluster of TmFd1 (Fig. 4b, trace i). Similarly, no [4Fe-4S] cluster EPR signal was observed when the reaction was performed without $\mathrm{NAD}^{+}$(Fig. 4b, trace ii). The typical rhombic feature of the reduced [ $4 \mathrm{Fe}-4 \mathrm{~S}$ ] cluster originating from $T m \mathrm{Fd} 1$ was observed only when the reaction mixture contained both $\mathrm{NAD}^{+}$and catalytic amounts of TmHydABC (Fig. 4b, trace iii). These results indicate that our holo-TmHydABC is 


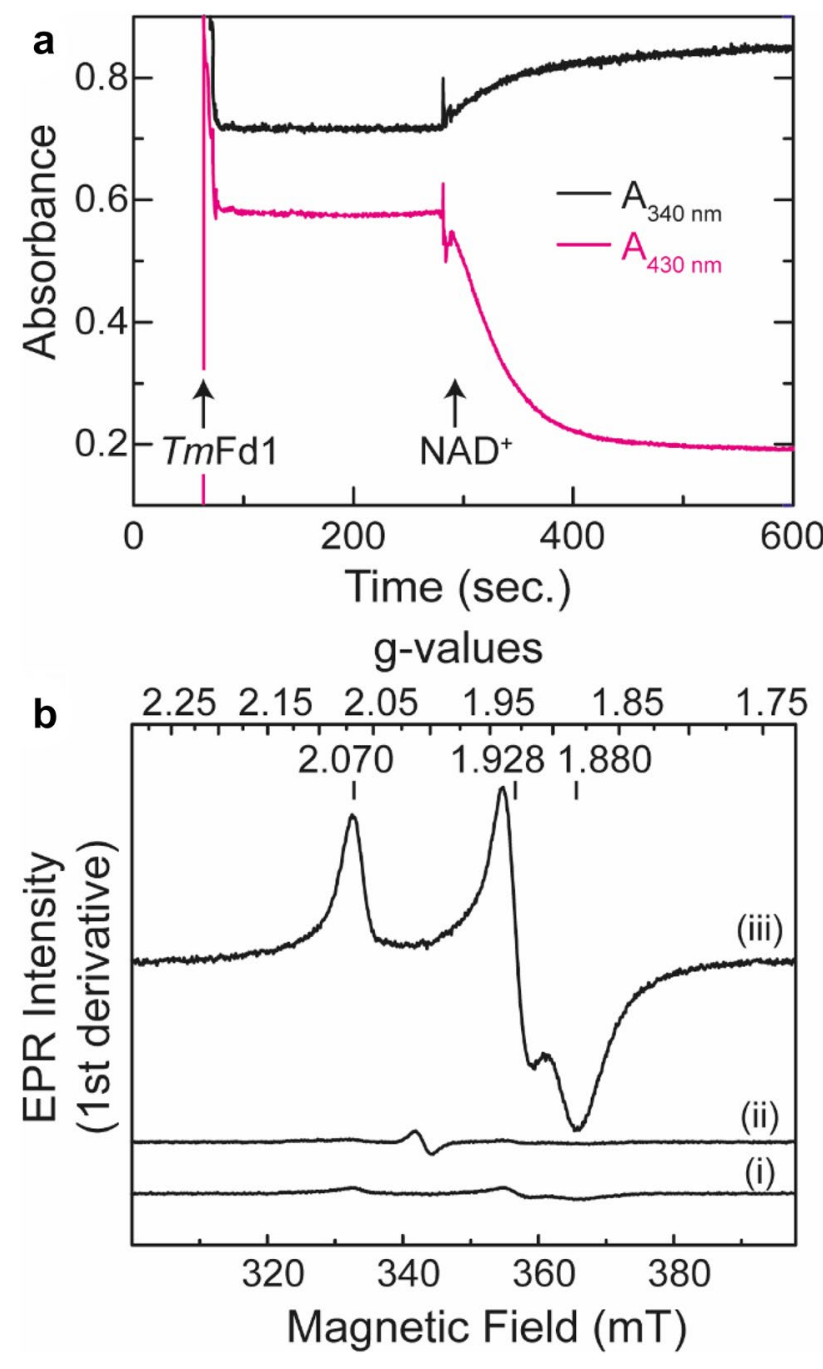

Fig. 4 Activity assay of TmHydABC using physiological partners. a Simultaneous reduction of $T m \mathrm{Fd} 1$ (decrease in $A_{430 \mathrm{~nm}}$ ) and $\mathrm{NAD}^{+}$ (increase in $A_{340 \mathrm{~nm}}$ ) by $\mathrm{TmHydABC}$ at $70{ }^{\circ} \mathrm{C}$ under an atmosphere of $100 \% \mathrm{H}_{2}$ was monitored by $\mathrm{UV}-\mathrm{Vis}$ spectroscopy. To a $1 \mathrm{~mL}$ reaction mixture containing $\approx 680 \mathrm{ng} T m \mathrm{HydABC}$ and $50 \mu \mathrm{M}$ FMN in $200 \mathrm{mM}$ potassium phosphate $(\mathrm{pH}$ 8) buffer, $\approx 35 \mu \mathrm{M} T m \mathrm{Fd} 1$ was added (indicated by the first arrow). To the same reaction mixture, $0.5 \mathrm{mM} \mathrm{NAD}^{+}$was added (indicated by the second arrow). b Reduction of $T m \mathrm{Fd} 1$ monitored by EPR spectroscopy. In the absence of TmHydABC, $\mathrm{H}_{2}$ did not reduce $T m \mathrm{Fd} 1$ (trace i). In the absence of $\mathrm{NAD}^{+}, T m \mathrm{HydABC}$ could not catalyze reduction of $T m \mathrm{Fd} 1$ from $\mathrm{H}_{2}$ (trace ii). However, when $\mathrm{NAD}^{+}$is present, $T m \mathrm{HydABC}$ could reduce TmFd1 using $\mathrm{H}_{2}$ as indicated by the appearance of the typical rhombic spectrum corresponding to the reduced $[4 \mathrm{Fe}-4 \mathrm{~S}]$ cluster. The conditions of the reactions used for preparing EPR samples were the same as for the UV-Vis measurements. The EPR spectra were measured at $10 \mathrm{~K}$ and at $0.2 \mathrm{~mW}$ power

capable of electron bifurcation in the presence of its physiological redox partners.

The specific activity of NADH production by TmHy$\mathrm{dABC}$ in the presence of $\mathrm{TmFd} 1$ at $70{ }^{\circ} \mathrm{C}$ was found to be $\approx 16.6 \mathrm{U} \mathrm{mg}^{-1}$ (Table $\mathrm{S} 1$ ), which is well within the range that was obtained for other electron-bifurcating [FeFe] hydrogenases [21, 27-29, 40]. The stoichiometry of NADH produced vs $T m F d 1$ reduced was found to be 1:2.01 ( \pm 0.1$)$, indicating that the reaction proceeds as expected according to Eq. (1) (Figure S9). Like the electron-bifurcating [FeFe] hydrogenase from Desulfovibrio fructosovorans (Hnd) [29], $T m \mathrm{HydABC}$ was also able to reduce $\mathrm{NAD}^{+}$in the absence of $T m \mathrm{Fd} 1$, however, at $\approx 35$-fold lower rate (Table S1). The specific activity of NADH production was found to be $\approx$ fivefold lower $\left(3.4 \pm 0.5 \mathrm{U} \mathrm{mg}^{-1}\right)$ when flavin adenine dinucleotide (FAD) was added to the assay buffer instead of FMN (Table S1). A similar observation was also made in the case of natively isolated $T m \mathrm{HydABC}$ that showed approximately $50 \%$ activity when FAD was added instead of FMN [14]. It is interesting to note that even in the absence of any FMN or FAD artificially maturated $T m$ HydABC could form NADH at $\approx$ fourfold lower rate $\left(4.7 \pm 0.6 \mathrm{U} \mathrm{mg}^{-1}\right)$ than when excess FMN was added to the assay mixture (Table S1, Figure S10). This residual activity appears to arise from the fraction of TmHydABC molecules that retained the FMN cofactor $(0.2 \pm 0.05$ moles of FMN per mole of $T m \mathrm{HydABC})$. From this observation, it can be concluded that the flavin cofactor required for the optimal bifurcation activity of $T m \mathrm{HydABC}$ is FMN and not FAD. Furthermore, this observation supports the idea that only one FMN per HydABC trimer is required for bifurcation and that a second flavin is highly unlikely to be present. Since the addition of excess FMN leads to an $\approx$ fourfold increase in rate, this indicates that the FMN content has likewise increased $\approx$ fourfold (from $\approx 0.2$ $\mathrm{FMN}$ per HydABC to $\approx 0.8$ ). If there were two sites, excess FMN would be expected to increase the FMN content $\approx$ tenfold, leading to a greater than tenfold increase in the rate. This finding has important implications for the bifurcation mechanism, which are discussed below.

\section{Spectroscopic characterization of the holo-protein}

The $\mathrm{CO}$ and $\mathrm{CN}^{-}$ligands coordinated to the iron atoms in the $\mathrm{H}$-cluster have characteristic stretching vibrations in the range $2150-1750 \mathrm{~cm}^{-1}$, where the characteristic amide vibrations from the protein backbone are absent. Since the stretching vibrations of these ligands are sensitive to changes in oxidation state of the metal center, Fourier transform infrared (FTIR) spectroscopy is an effective tool to study the redox intermediates of the $\mathrm{H}$-cluster. The characteristic FTIR bands for the various redox states of some well-characterized $[\mathrm{FeFe}]$ hydrogenases are presented in Table S2.

EPR spectroscopy is an additional tool providing information about the paramagnetic species present in the various redox states of the hydrogenase. Characteristic $g$ values for the redox states of some well-characterized hydrogenases are presented in Table S3. 


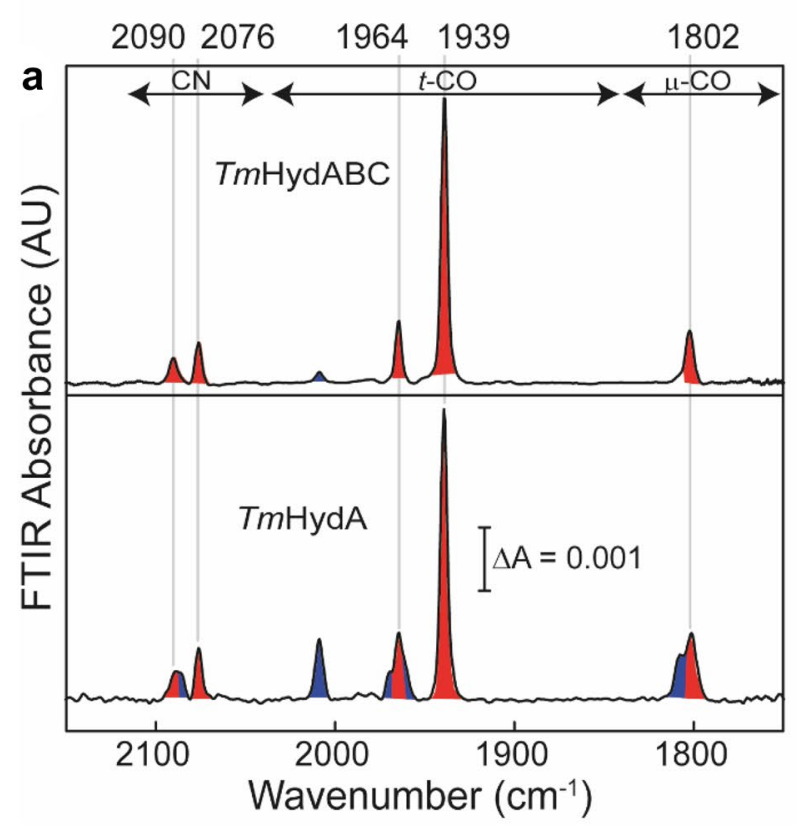

Fig. 5 FTIR and EPR spectra of artificially maturated TmHydABC and TmHydA under oxidizing conditions. a Top panel shows the FTIR spectrum of $400 \mu \mathrm{M} T m \mathrm{HydABC}$ oxidized with $20 \mathrm{mM} \mathrm{NAD}^{+}$ and the lower panel shows the FTIR spectrum of $400 \mu \mathrm{M}$ TmHydA oxidized with $1 \mathrm{mM}$ thionine. Both samples were in $0.1 \mathrm{M}$ Tris- $\mathrm{HCl}$ $\mathrm{pH} 8$ buffer, $0.15 \mathrm{M} \mathrm{NaCl}$ and the spectra were measured at room temperature. The peaks belonging to the $\mathrm{H}_{\mathrm{ox}}$ state are shaded in red and those belonging to the $\mathrm{H}_{\mathrm{ox}}-\mathrm{CO}$ state are shaded in blue. b CW

\section{Characterization of the oxidized state}

After artificial maturation, both $T m \mathrm{HydABC}$ and $T m \mathrm{HydA}$ were obtained in a mixture of oxidation states (Figure S6). Various redox agents were used to enrich the individual oxidation states. Figure 5 shows the FTIR and EPR spectra of $T m \mathrm{HydABC}$ and $T m \mathrm{HydA}$ after oxidizing the proteins with $\mathrm{NAD}^{+}$and thionine, respectively. In both cases, the FTIR spectra (Fig. 5a) are characterized by five major FTIR bands (2090, 2076, 1964, 1939, and $\left.1802 \mathrm{~cm}^{-1}\right)$. The positions of these bands are comparable to those reported for the $\mathrm{H}_{\mathrm{ox}}$ state of $T m \mathrm{HydABC}$ isolated from the native organism [30] and also to those reported for other $[\mathrm{FeFe}]$ hydrogenases (Table S2). It is, therefore, reasonable to assume that the $\mathrm{H}$-cluster of both $T m \mathrm{HydABC}$ and $\mathrm{TmHydA}$ are mostly in the $\mathrm{H}_{\mathrm{ox}}$ state under the applied oxidizing conditions.

In the $\mathrm{H}_{\mathrm{ox}}$ state, both irons in the $[2 \mathrm{Fe}]_{\mathrm{H}}$ subsite are in a low spin configuration leading to an $S=1 / 2$ ground state for $\mathrm{H}_{\mathrm{ox}}$. In this electronic configuration, the H-cluster shows a rhombic EPR spectrum with two $g$ values above 2.0. Figure $5 \mathrm{~b}$ shows the $\mathrm{CW}$ X-band EPR spectra of oxidized $T m$ HydABC and TmHydA. The experimental spectra of both $T m \mathrm{HydABC}$ and $T m \mathrm{HydA}$ were simulated with three

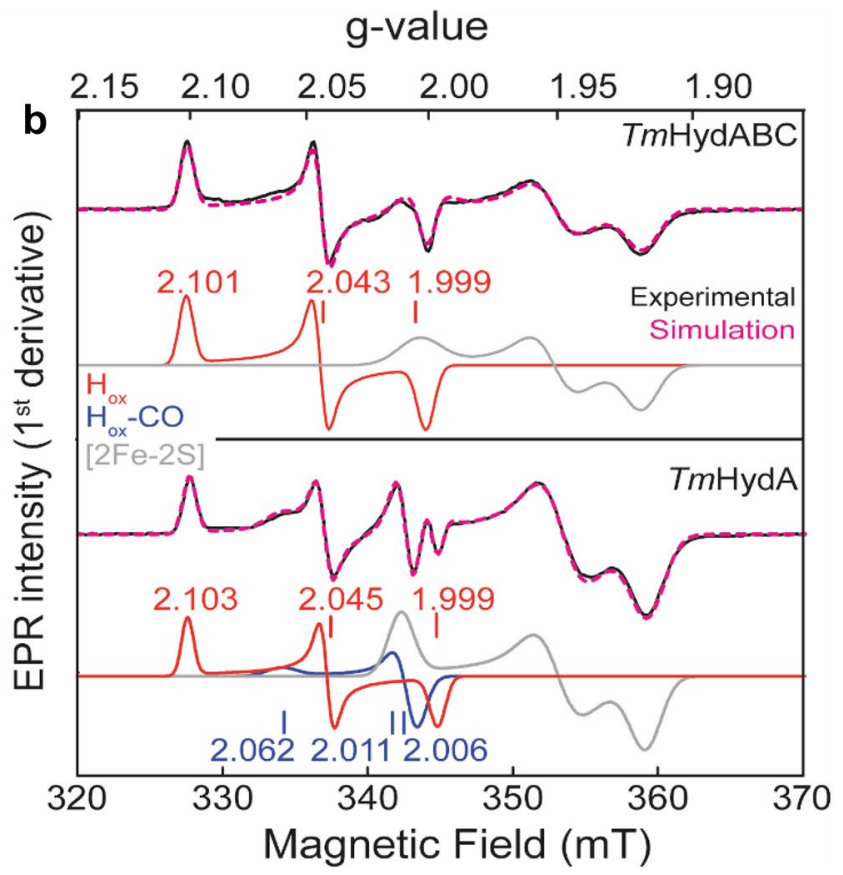

X-band EPR spectra of the oxidized TmHydABC and TmHydA samples at $20 \mathrm{~K}, 0.1 \mathrm{~mW}$ microwave power. The samples were prepared in the same way as for the FTIR measurements. The experimental spectra are overlaid with spectral simulations (dotted magenta lines) and the component spectra are shown underneath. The red trace (Component 1) corresponds to the $\mathrm{H}_{\mathrm{ox}}$ state, the blue trace (Component 2) corresponds to the $\mathrm{H}_{\mathrm{ox}}-\mathrm{CO}$ state and the gray trace (Component 3 ) corresponds to one of the reduced F-clusters

components (details of the EPR simulations are given in Table S4). For both TmHydABC and TmHydA, Component 1 is a rhombic EPR spectrum with almost identical $g$ values; 2.102, 2.044, and 1.998 for TmHydABC and 2.103, 2.045, and 1.999 for TmHydA (Fig. 5b). These $g$ values are in good agreement with the $g$ values of the $\mathrm{H}_{\mathrm{ox}}$ state of other $[\mathrm{FeFe}]$ hydrogenases (Table S3). Thus, the $\mathrm{H}_{\mathrm{ox}}$ state is also observed for TmHydABC and TmHydA by EPR after oxidative treatment. The additional Component 2 can be assigned to the $\mathrm{H}_{\mathrm{ox}}-\mathrm{CO}$ state, and indications of its presence were also observed in the FTIR spectra (Fig. 5a, peaks shaded in blue). The third component with $g$ values of $[2.013,1.950,1.917]$ for $T m H y d A B C$ and $[2.005,1.949$, 1.918] for TmHydA (Table S4) can be assigned to reduced FeS clusters based on the similarity to the spectra of reduced apo-TmHydABC and apo-TmHydA (Figure S5B). When the EPR spectrum of the NAD ${ }^{+}$oxidized $T m \mathrm{HydABC}$ sample was measured at higher temperature $(40 \mathrm{~K})$, signals corresponding to Component 3 could still be observed, which indicated that this signal is originating from a slowly relaxing [2Fe-2S] cluster (Figure S11). EPR spin quantitation on the oxidized holo-TmHydABC sample gave a spin content of $\approx 0.6$ spins/molecule of protein for the $\mathrm{H}_{\mathrm{ox}}$ component 
and $\approx 0.1$ spins/molecule of protein for the $\mathrm{H}_{\mathrm{ox}}-\mathrm{CO}$ component. Therefore, the total spin content of the H-cluster is approximately 0.7 spins/molecule of protein. In the case of native $T m \mathrm{HydABC}$ the spin content originating from the $\mathrm{H}$-cluster was found to be $\approx 0.1 \mathrm{spin} /$ molecule of protein [26], indicating a larger proportion of intact H-clusters in the TmHydABC sample prepared by our method, which could also explain the higher activity found in solution compared with that reported for the native enzyme [26].

\section{Characterization of the CO-inhibited state}

$\mathrm{CO}$ is a well-known competitive inhibitor for [FeFe] hydrogenases by occupying the open coordination site of the $\mathrm{H}$-cluster to form the $\mathrm{H}_{\mathrm{ox}}-\mathrm{CO}$ state, a well-defined state showing characteristic EPR and FTIR signals [1, 41, 42]. FTIR and EPR spectra of the $\mathrm{H}_{\mathrm{ox}}-\mathrm{CO}$ state of TmHydABC and $T m$ HydA are shown in Fig. 6.

FTIR spectra of CO-inhibited TmHydABC and TmHydA are virtually identical and are characterized by the same IR bands at 2092 and $2085 \mathrm{~cm}^{-1}$ for the $\mathrm{CN}^{-}$ligands; 2008, 1970 and $1961 \mathrm{~cm}^{-1}$ for the terminal CO ligands and $1807 \mathrm{~cm}^{-1}$ for the bridging CO ligand. The FTIR bands of the $\mathrm{CO}$ ligands are in very good agreement with those recently published for native TmHydABC [30]. Both the $\mathrm{CN}^{-}$and $\mathrm{CO}$ IR-stretching frequencies are very similar to those reported for the $\mathrm{H}_{\mathrm{ox}}-\mathrm{CO}$ state of other [FeFe] hydrogenases (Table S2).

The experimental EPR spectra of CO-inhibited TmHy$\mathrm{dABC}$ and $\mathrm{TmHydA}$ indicate the presence of two paramagnetic species. The almost axial EPR spectra with $g$ values [2.064, 2.008, 2.005] for TmHydABC and [2.062, 2.011, 2.006] for $T m \mathrm{HydA}$ are similar to those from the $\mathrm{H}_{\text {ox }}-\mathrm{CO}$ state of other [ $\mathrm{FeFe}]$ hydrogenases (Table S3) and arise from the low spin iron centers in the mixed valence $[\mathrm{Fe}(\mathrm{I})$ $\mathrm{Fe}(\mathrm{II})]_{\mathrm{H}}$, analogous to the $\mathrm{H}_{\mathrm{ox}}$ state. The oxidized sample of TmHydABC isolated from the native organism showed features at $g=2.070,2.024$, and 2.002 [26]. The EPR lines at 2.070 and 2.002 are similar to the $\mathrm{H}_{\mathrm{ox}}-\mathrm{CO}$ EPR signature observed here for artificially maturated $T m \mathrm{HydABC}$ or for other $[\mathrm{FeFe}]$ hydrogenases. The second paramagnetic species observed in the EPR spectra of the $\mathrm{H}_{\mathrm{ox}}-\mathrm{CO}$ state can be assigned to a reduced [2Fe-2S] cluster, as it has $g$ values and line shapes similar to those observed for the third component in the EPR spectra of the $\mathrm{H}_{\text {ox }}$ samples.

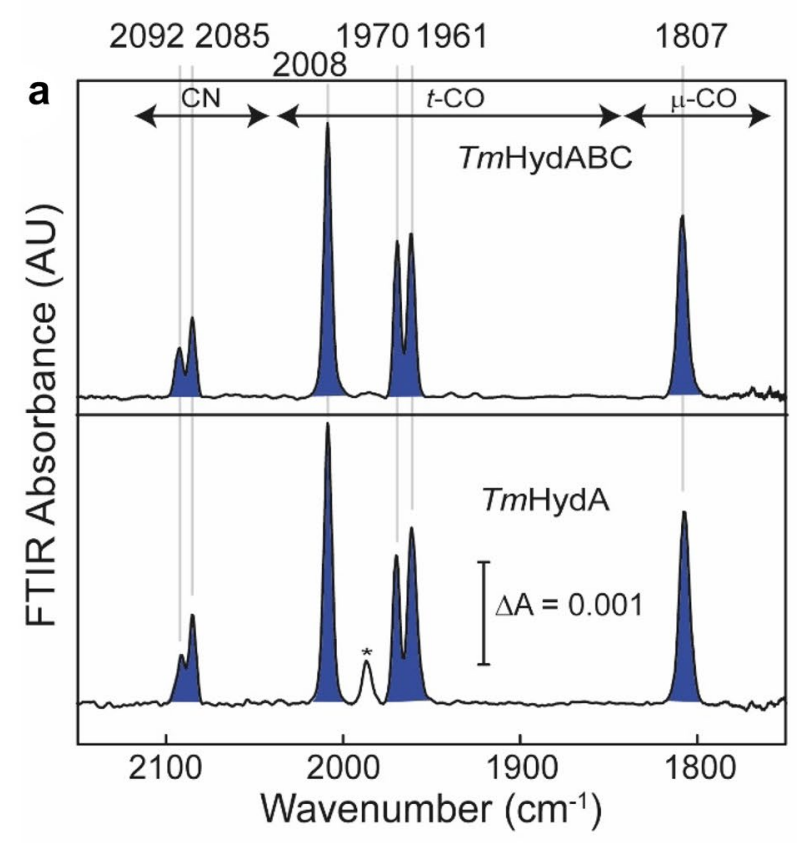

Fig. 6 FTIR and EPR spectra of TmHydABC and TmHydA after $\mathrm{CO}$ inhibition. a FTIR spectra of CO-inhibited $\left(\mathrm{H}_{\mathrm{ox}}-\mathrm{CO}\right)$ artificially maturated $T m \mathrm{HydABC}$ and $T m \mathrm{HydA}$. The 'as-isolated' protein samples $(\approx 400 \mu \mathrm{M})$ were purged for 20 min with $100 \% \mathrm{CO}$, followed by incubation for an additional $60 \mathrm{~min}$. Spectra were measured at room temperature. The peak marked with an asterisk belongs to an unidentified species. b CW X-band EPR spectra of CO-inhibited $\left(\mathrm{H}_{\mathrm{ox}}-\mathrm{CO}\right)$

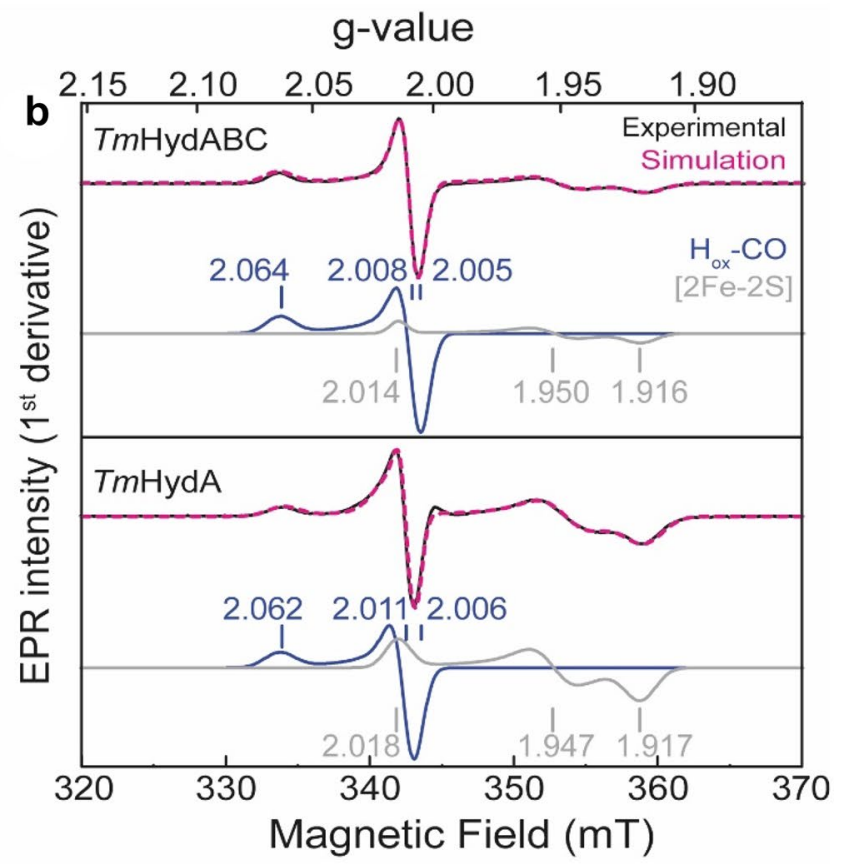

TmHydABC and TmHydA measured at $20 \mathrm{~K}$ and $0.1 \mathrm{~mW}$ microwave power. Approximately, $150 \mu \mathrm{M}$ of each protein in $0.1 \mathrm{M}$ Tris $-\mathrm{HCl}$ buffer $\mathrm{pH} 8,0.15 \mathrm{M} \mathrm{NaCl}, 20 \%$ glycerol, were purged for $20 \mathrm{~min}$ with $100 \%$ CO, before measuring the spectra. The experimental spectra are overlaid with the spectral simulations (dotted magenta line) and the components are shown underneath 


\section{Characterization of the reduced state}

Reduction of the Fe-centers in the H-cluster causes redshifts of the FTIR peaks (with respect to $\mathrm{H}_{\mathrm{ox}}$ ) of the $\mathrm{CO}$ and $\mathrm{CN}^{-}$ligands due to increases of electron density in anti-bonding ligand orbitals, which lengthens the $\mathrm{CO}$ and $\mathrm{CN}^{-}$bonds [43]. This effect is largest when reduction takes place at the $[2 \mathrm{Fe}]_{\mathrm{H}}$ subcluster $\left(20-50 \mathrm{~cm}^{-1}\right)$; however, small red-shifts $\left(\approx 10 \mathrm{~cm}^{-1}\right)$ are also observable when the $[4 \mathrm{Fe}-4 \mathrm{~S}]_{\mathrm{H}}$ subcluster is reduced [8]. When reduced with sodium dithionite, FTIR spectra of TmHydABC and $T m$ HydA are identical and showed five major IR bands at 2075, 2037, 1956, 1919, and $1887 \mathrm{~cm}^{-1}$ (Fig. 7a). All these bands are significantly red-shifted (by $20-50 \mathrm{~cm}^{-1}$ ) as compared to the $\mathrm{H}_{\mathrm{ox}}$ state indicating reduction of the $[2 \mathrm{Fe}]_{\mathrm{H}}$ subsite. They resemble closely those for the $\mathrm{H}_{\text {red }} \mathrm{H}^{+}$state identified in other [FeFe] hydrogenases (see Table S2). It is to be noted here that in the $\mathrm{H}_{\text {red }} \mathrm{H}^{+}$state, the bridging $\mathrm{CO}$ vibration is absent in both TmHydABC and TmHydA; however, an additional peak is observed at $1956 \mathrm{~cm}^{-1}$ (Fig. 7a), which may indicate that in the $\mathrm{H}_{\text {red }} \mathrm{H}^{+}$state the bridging $\mathrm{CO}$ becomes terminal, as was proposed for the $\mathrm{H}_{\text {red }} \mathrm{H}^{+}$state in the $[\mathrm{FeFe}]$ hydrogenases from Chlamydomonas reinhardtii (CrHydA1) and Desulfovibrio desulfuricans (DdHydAB)

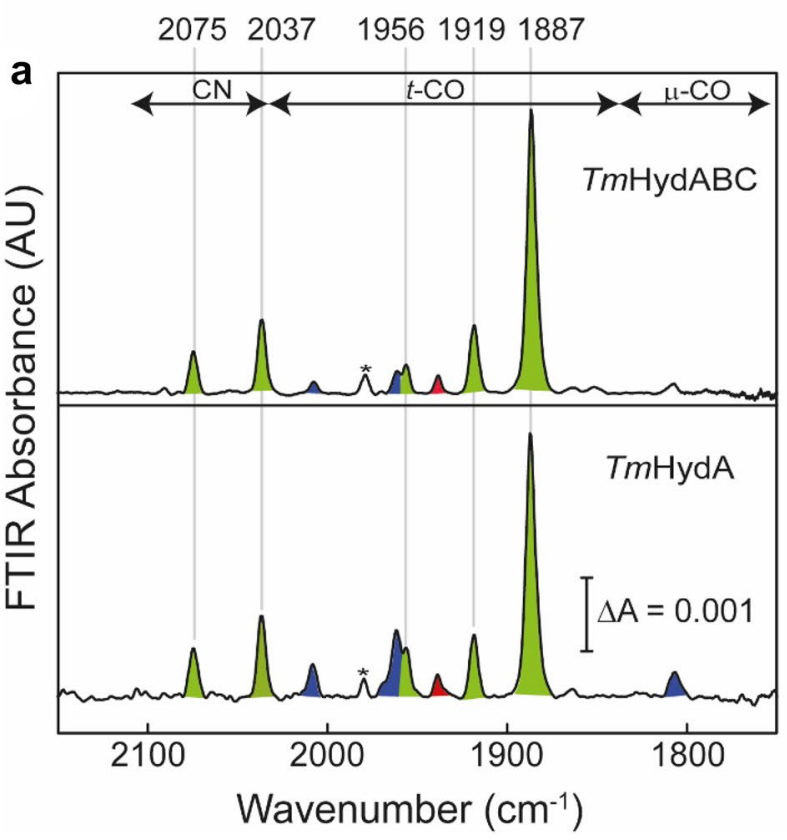

Fig. 7 FTIR and EPR spectra of the reduced TmHydABC and TmHydA. a FTIR spectra of reduced TmHydABC or TmHydA samples are shown in the upper and lower panels, respectively. Approximately $400 \mu \mathrm{M}$ of 'as-isolated' protein samples were incubated with $20 \mathrm{mM}$ of sodium dithionite (NaDT) at room temperature for $5 \mathrm{~min}$ before measuring the spectra at room temperature. The peaks corresponding to the $\mathrm{H}_{\text {red }} \mathrm{H}^{+}$state are shaded in green. The minor peaks
$[8,44,45]$. However, in a recent study, it was suggested that the bridging $\mathrm{CO}$ can be retained in the $\mathrm{H}_{\mathrm{red}} \mathrm{H}^{+}$state under certain conditions [46].

Due to the antiferromagnetic spin coupling in the $[\mathrm{Fe}(\mathrm{I})$ $\mathrm{Fe}(\mathrm{I})]$ unit, the H-cluster in the $\mathrm{H}_{\text {red }} \mathrm{H}^{+}$state is EPR silent, but the reduced F-clusters give rise to a characteristic EPR spectrum consisting of multiple contributions from $[4 \mathrm{Fe}-4 \mathrm{~S}]^{+}$and $[2 \mathrm{Fe}-2 \mathrm{~S}]^{+}$clusters (Fig. $7 b$ ) very similar to the EPR spectrum observed for the reduced apo-enzyme (Figure S5B) and that of the reduced native enzyme [26, 38, 47]. Interestingly, the dominant contribution with $g$ values ([2.004, 1.950, 1.920] for TmHydABC and [2.004, 1.955, 1.923] for $T m \mathrm{HydA}$ ) is also present in the $\mathrm{H}_{\mathrm{ox}}$ and $\mathrm{H}_{\mathrm{ox}}-\mathrm{CO}$ states (Figs. 5b, 6b) and was tentatively assigned to one of the two $[2 \mathrm{Fe}-2 \mathrm{~S}]^{+}$clusters in the HydA subunit.

\section{Spectroelectrochemical characterization of TmHydABC}

Spectroelectrochemical FTIR was used previously in studies of several $[\mathrm{FeFe}]$ hydrogenases to investigate their equilibrium redox properties and to calculate midpoint potentials $[7,44]$. Here, we apply this method to characterize the potential dependence of the observed redox states in

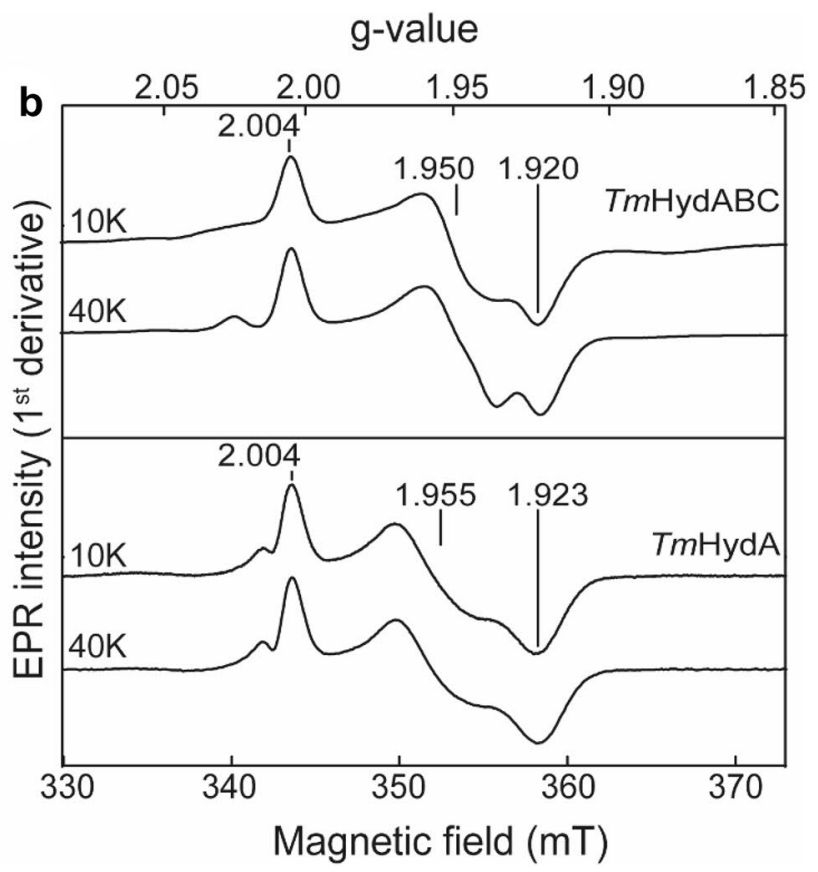

shaded in blue and red belong to the $\mathrm{H}_{\mathrm{ox}}-\mathrm{CO}$ and $\mathrm{H}_{\mathrm{ox}}$ states. The peak marked with an asterisk belongs to an unidentified species. b CW X-band EPR spectra of reduced protein samples (TmHyd$\mathrm{ABC}$ and $T m \mathrm{HydA})$ were measured at $10 \mathrm{~K}(0.01 \mathrm{~mW}$ microwave power) and $40 \mathrm{~K}$ (1 $\mathrm{mW}$ microwave power). EPR sample composition: $150 \mu \mathrm{M}, 10 \mathrm{mM}$ of NaDT, $0.1 \mathrm{M}$ Tris- $\mathrm{HCl}$ buffer $\mathrm{pH} 8,0.15 \mathrm{M}$ $\mathrm{NaCl}, 20 \%$ glycerol 


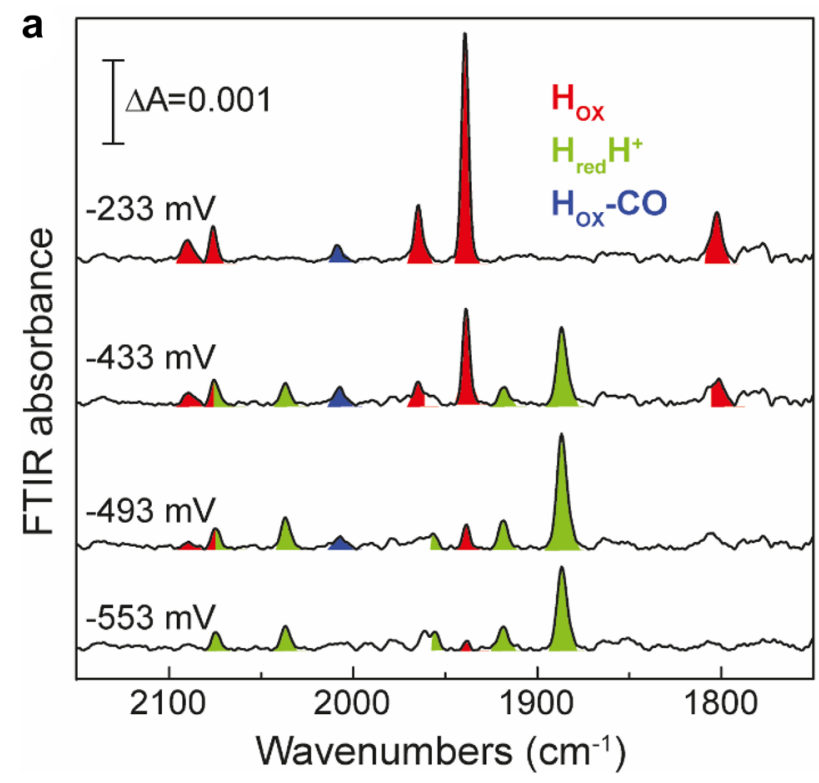

Fig. 8 Spectroelectrochemical FTIR of TmHydABC. a Selected FTIR spectra recorded at $-233,-433,-493$ and $-553 \mathrm{mV}$ are shown. The experiment was performed with $\approx 1 \mathrm{mM} \mathrm{TmHydABC}$ in $200 \mathrm{mM}$ phosphate buffer $(\mathrm{pH} 8)$ and $200 \mathrm{mM} \mathrm{KCl}$ with redox mediators at $15^{\circ} \mathbf{C}$. b Changes in FTIR absorbance with changing electrode poten-

TmHydABC. The reductive titration of $T m \mathrm{HydABC}$ was initiated at an open-circuit potential (OCP) of $\approx-230 \mathrm{mV}$, vs SHE. The FTIR spectrum recorded at this potential suggested that the protein is mainly in the $\mathrm{H}_{\mathrm{ox}}$ state (Fig. 8a). As the potential of the cell was decreased, the peaks corresponding to the $\mathrm{H}_{\mathrm{ox}}$ state decreased in intensity and were replaced by the peaks that were previously observed in the dithionite reduced enzyme (Fig. 8a). However, when the potential was decreased lower than $\approx-500 \mathrm{mV}$, the intensity of these peaks decreased but no new peaks appeared, indicating irreversible degradation of the H-cluster (Fig. 8a, b).

The reductive titration curve obtained by plotting the intensities of the bands at $1939 \mathrm{~cm}^{-1}\left(\mathrm{H}_{\mathrm{ox}}\right)$ and $1887 \mathrm{~cm}^{-1}$ $\left(\mathrm{H}_{\text {red }} \mathrm{H}^{+}\right)$vs. the applied potential could be fitted using the Nernst equation corresponding to a one-electron reduction (Fig. 8b, c). This fitting revealed that the state characterized by bands at 2075, 2037, 1956, 1919, and $1886 \mathrm{~cm}^{-1}$ is indeed one electron reduced with respect to the $\mathrm{H}_{\mathrm{ox}}$ state, and further supporting that this state is $\mathrm{H}_{\text {red }} \mathrm{H}^{+}$. The redox potential associated with the $\mathrm{H}_{\mathrm{ox}} / \mathrm{H}_{\text {red }} \mathrm{H}^{+}$transition for TmHydABC at $\mathrm{pH} 8$ (Fig. 8b) was found to be $-420 \pm 5 \mathrm{mV}$, which is similar to that reported for $D d \mathrm{HydAB}[44,45]$.

The $\mathrm{H}_{\text {red }} \mathrm{H}^{+}$state is formed by proton coupled electron transfer (PCET) of the $\mathrm{H}_{\mathrm{ox}}$ state [8]. In CrHydA1, which lacks the F-clusters, both $\mathrm{H}_{\text {red }}$ and $\mathrm{H}_{\text {red }} \mathrm{H}^{+}$can be observed at neutral $\mathrm{pH}$ and the apparent $\mathrm{pKa}$ of the ADT amine is around 7.2 [8]. In contrast, for $D d \mathrm{Hyd} \mathrm{AB}$ which harbors two F-clusters, the apparent pKa was found to be 9.0 [45].
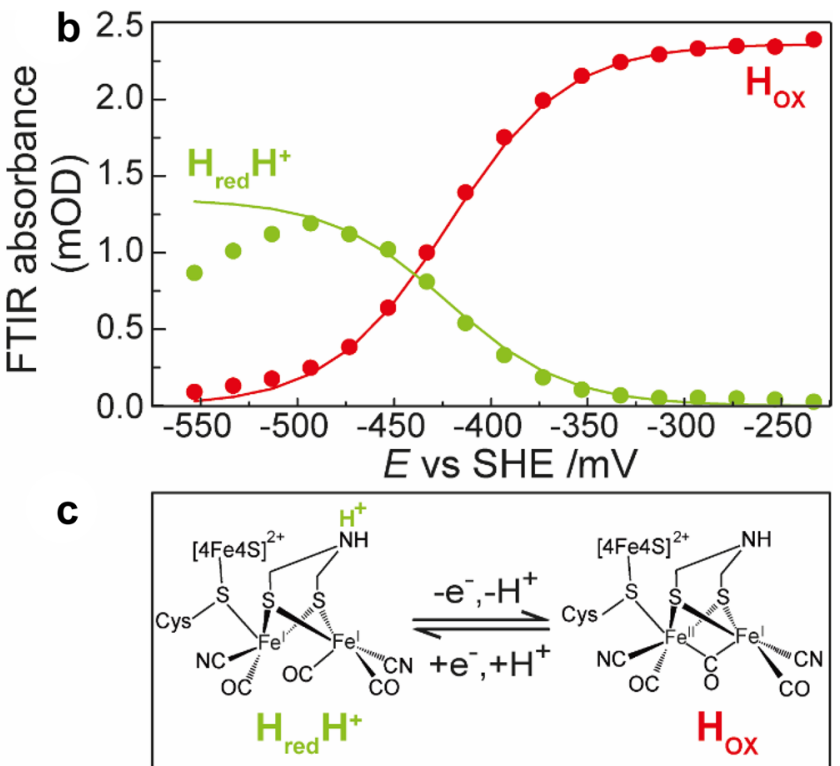

tial, during reductive titration, at peak position $1939 \mathrm{~cm}^{-1}\left(\mathrm{H}_{\mathrm{ox}}\right)$ and $1887 \mathrm{~cm}^{-1}\left(\mathrm{H}_{\mathrm{red}} \mathrm{H}^{+}\right)$are shown by red and green circles, respectively. The solid red and green lines represent the Nernst-fit corresponding to the model shown in $\mathbf{c}$ -

This difference is explained by the influence of the proximal F-cluster on the redox potential of the $[4 \mathrm{Fe}-4 \mathrm{~S}]_{\mathrm{H}}$ subcluster. Redox anti-cooperativity (redox interaction between the $\mathrm{F}$ - and $\mathrm{H}$-clusters that decreases the reduction potential of the $\mathrm{H}$-cluster when the proximal F-cluster is reduced and vice versa), disfavors reduction of the $[4 \mathrm{Fe}-4 \mathrm{~S}]_{\mathrm{H}}$ subcluster, thus promoting direct PCET from the proximal F-cluster to the $[2 \mathrm{Fe}]_{\mathrm{H}}$ subcluster upon reduction of the $\mathrm{H}$-cluster. This mechanism increases the apparent pKa of the ADT amine moiety [45]. During the spectroelectrochemical titration of $T m \mathrm{HydABC}$ at $\mathrm{pH} 8$, we did not observe any $\mathrm{H}_{\text {red }}$ state (Fig. 8). The $\mathrm{H}_{\text {red }}$ state was also not observed when the FTIR spectrum of dithionite reduced $\mathrm{TmHydABC}$ was measured at $\mathrm{pH} 10$ (Figure S12). The exceptionally high apparent $\mathrm{pKa}$ of the ADT amine in TmHydABC could be the result of structural modifications in the $\mathrm{H}$-cluster binding pocket with respect to $D d \mathrm{HydAB}$ and $C r \mathrm{HydA} 1$ that reinforce the effect of redox anti-cooperativity with the proximal F-cluster(s).

Artificial maturation with the unprotonatable $[2 \mathrm{Fe}]^{\mathrm{ADT}}$-analogue $[2 \mathrm{Fe}]^{\mathrm{PDT}}[48,49]$ confirmed that an unprotonated reduced state of $T m \mathrm{Hyd} \mathrm{ABC}$ is indeed accessible. The $[2 \mathrm{Fe}]^{\mathrm{PDT}}$-maturated $\mathrm{Tm} \mathrm{HydABC}$ exhibits an $\mathrm{H}_{\text {red }}$ state with very low signal intensity and broadened peaks (Figure S13). The reason for this is unclear, but may be related to some conformational freedom of the $[2 \mathrm{Fe}]$ site in this enzyme. Furthermore, we found no evidence for the formation of a two electron reduced state (the $\mathrm{H}_{\text {sred }} \mathrm{H}^{+}$state) in our spectroelectrochemistry data (Fig. 8). Formation of 
the $\mathrm{H}_{\text {sred }} \mathrm{H}^{+}$state was proposed to be essential for $\mathrm{CrHydA1}$ during $\mathrm{H}_{2}$ production [9]. For $D d \mathrm{HydAB}$, an [FeFe] hydrogenase containing F-clusters, it was proposed that it can avoid the formation of the $\mathrm{H}_{\text {sred }} \mathrm{H}^{+}$state, as the nearby F-clusters can accept the second electron and can tunnel it quickly to the H-cluster during catalysis [45]. A similar phenomenon is also likely to be operative in $T m \mathrm{HydABC}$ leading to the absence of $\mathrm{H}_{\text {sred }} \mathrm{H}^{+}$, although the protein is catalytically highly active. It should be noted that in a recent kinetics study on native $T m \mathrm{HydABC}$, the bands assigned to $\mathrm{H}_{\text {red }} \mathrm{H}^{+}$in our study were attributed to the doubly reduced state $\mathrm{H}_{\text {sred }} \mathrm{H}^{+}$with some contribution from $\mathrm{H}_{\text {red }} \mathrm{H}^{+}$(referred to as " $\mathrm{H}_{\text {sred }}$ " and " $\mathrm{H}_{\text {red }}$ ", respectively) [30]. We believe that as the positions of the FTIR bands of the $\mathrm{H}_{\text {red }} \mathrm{H}^{+}$and $\mathrm{H}_{\text {sred }} \mathrm{H}^{+}$ states are very similar, correct assignment of bands to these two states is difficult without electrochemical titrations. The main conclusions of this kinetics study, however, are not affected by this misassignment [30]. The protonated reduced state did occur under proton reduction conditions and was identified as a catalytically active state [30].

\section{Discussion}

In this study, the heterotrimeric electron-bifurcating [FeFe] hydrogenase from T. maritima, TmHydABC, and its catalytic subunit $T m$ HydA was produced by recombinant expression and artificial maturation. With artificial redox partners, semisynthetically produced $T m \mathrm{HydABC}$ and $\mathrm{TmHydA}$ showed significantly higher $\mathrm{H}_{2}$ production $\left(550 \pm 50 \mathrm{U} \mathrm{mg}^{-1}\right.$ and $\left.475 \pm 60 \mathrm{U} \mathrm{mg}^{-1}\right)$ and $\mathrm{H}_{2}$ oxidation activities $(1300 \pm 140$ and $2000 \pm 200 \mathrm{U} \mathrm{mg}^{-1}$ ) at $70{ }^{\circ} \mathrm{C}$ compared to the enzyme isolated from the native organism [26]. Native $T m \mathrm{HydABC}$ was previously found to use both reduced ferredoxin and $\mathrm{NADH}$ as electron donors for $\mathrm{H}_{2}$ production, thereby acting as an electron-confurcating hydrogenase [14]. Here, we show that the semisynthetically produced holo- $T m \mathrm{HydABC}$ could catalyze the reverse reaction, i.e., $\mathrm{H}_{2}$-dependent reduction of ferredoxin only in the presence of $\mathrm{NAD}^{+}$, demonstrating that the enzyme is also capable of the electron bifurcation reaction.

We have used FTIR and EPR spectroscopy to analyze the salient features of the H-cluster in TmHydABC and TmHydA under various conditions. Under oxidizing conditions, both $T m$ HydABC and TmHydA showed spectral properties (positions of the FTIR peaks and EPR $g$ values) similar to the $\mathrm{H}_{\mathrm{ox}}$ state of prototypical [FeFe] hydrogenases (non-electron bifurcating) (Fig. 5, Tables S1 and S2). Furthermore, when we treated $T m \mathrm{HydABC}$ and $T m \mathrm{HydA}$ with CO, FTIR, and EPR spectroscopic features of the $\mathrm{H}_{\text {ox }}-\mathrm{CO}$ state could be identified. This observation implies that like prototypical $[\mathrm{FeFe}]$ hydrogenases, the $\mathrm{H}$-cluster of electronbifurcating hydrogenases is also inhibited by $\mathrm{CO}$. All these results suggest that properties of the H-cluster of TmHyd$\mathrm{ABC}$ are similar to those of the prototypical [FeFe] hydrogenases. This was expected as the amino acid sequences surrounding the H-cluster pocket are well conserved in electron-bifurcating and non-electron-bifurcating [FeFe] hydrogenases [50]. However, the previously published EPR spectroscopic analysis of native $T m \mathrm{HydABC}$ did not identify the characteristic EPR signal of the $\mathrm{H}_{\mathrm{ox}}$ state [26], which led to the speculation that the $\mathrm{H}$-cluster of electron-bifurcating enzymes is different from prototypical enzymes [51].

Electron bifurcation refers to the process of splitting the electrons from a single electron donor to two different electron acceptors, one with higher redox potential and the other with lower redox potential than that of the electron donor $[16,17]$. Electron-bifurcating enzymes usually contain at least one flavin along with several other redox centers and it is presumed that the bifurcation reaction happens at this flavin as this cofactor is capable of both one and two electron transfer reactions (flavin-based electron bifurcation, FBEB) $[16,51]$. In general, the flavin centers responsible for FBEB show special redox properties [52]. These flavins display 'crossed' redox potentials: they undergo $2 \mathrm{e}^{-}$reduction from the flavoquinone state to the flavohydroquinone state and, then, upon $1 \mathrm{e}^{-}$oxidation, form a highly reducing flavosemiquinone state that can transfer electrons to low potential electron acceptors.

FBEB has been suggested to operate in $T m \mathrm{HydABC}$ and other electron-bifurcating [FeFe] hydrogenases [23]. Protein sequence analysis of $T m \mathrm{HydABC}$ and other electronbifurcating $[\mathrm{FeFe}]$ hydrogenases indicates the presence of one FMN-binding site in $\mathrm{HydB}$. Based on the sequence similarity between $\mathrm{HydB}$ and the NuoF (Nqo1) subunit of respiratory complex I [23], whose FMN does not engage in electron bifurcation, it seems unlikely that the FMN in HydB would be the site of electron bifurcation. Thus, the involvement of a second flavin for electron bifurcation was proposed in TmHydABC [23]. Here, we showed that TmHyd$\mathrm{ABC}$ containing $0.2 \mathrm{FMN}$ per heterotrimer catalyzed the electron bifurcation reaction with a rate of $28 \%$ of that in the presence of added excess FMN. This fits with the idea that only one FMN per trimer is necessary for electron bifurcation. If two FMN sites were present then the $0.2 \mathrm{FMN}$ would be split between the two sites, with 0.1 FMN per site (or $10 \%$ occupancy of each site) assuming equal affinity for both sites. By the law of probabilities then, only $1 \%$ of HydABC would have both sites occupied. If both FMN sites were essential for the catalytic mechanism (one for NADH oxidation and one for electron bifurcation), then, in this scenario, the addition of excess FMN should fill up all empty FMN sites and increase the activity accordingly by about 100 -fold. Therefore, the modest fourfold increase in activity, contradicts the proposition of a second flavin being the bifurcation center in TmHydABC. 


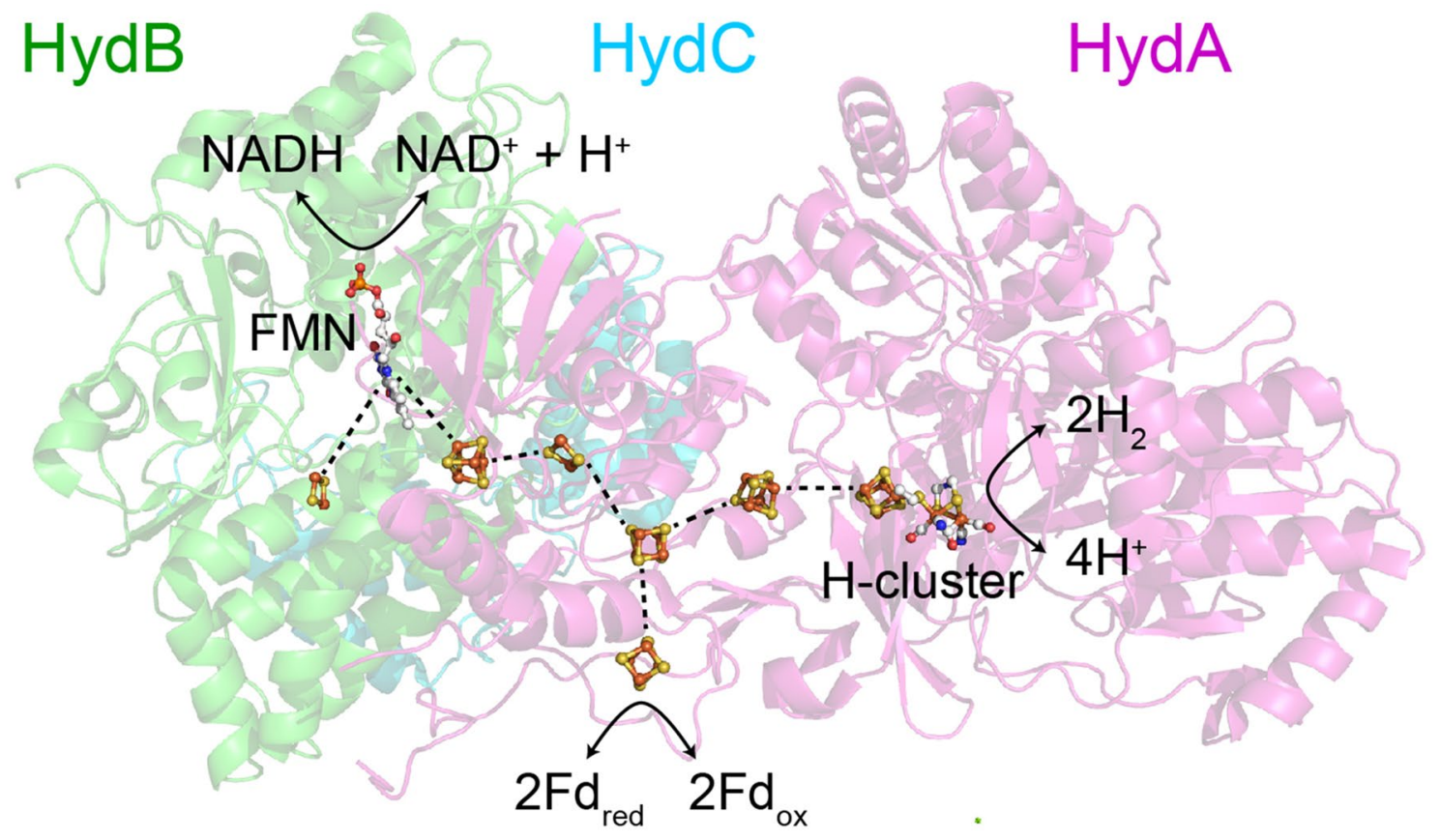

Fig. 9 Proposed arrangement of subunits and cofactors in TmHydABC. The TmHydABC subunits are homologous to the Nqo1, Nqo2, and Nqo3 subunits of the structurally characterized complex I from Thermus thermophilus. Based on this homology, the arrangements of the conserved cofactors can be predicted. The figure shows the protein subunits Nqo1 (HydB, green), Nqo2 (HydC, blue), and Nqo3 (HydA, pink) in the cartoon representation (PDB: 4HEA [53],), with the cofactors from Nqo1 and Nqo2 from complex I, and the cofac-

More recently, an alternative model of the bifurcation mechanism in $[\mathrm{FeFe}]$ hydrogenases has been postulated by Peters et al. where the $\mathrm{H}$-cluster was hypothesized to be the electron bifurcation site [51]. The rationale behind this hypothesis was that the H-cluster fulfills one of the key requirements of being an electron-bifurcation center, as it is capable of $2 \mathrm{e}^{-}$redox reactions and can exist in different oxidation states. Like electron-bifurcating flavins, the intermediate redox state of the H-cluster should be strongly reducing in order for it to be an electron bifurcation center [52]. Our spectroelectrochemical analysis of $T m \mathrm{HydABC}$ shows that the $\mathrm{H}$-cluster forms a stable $1 \mathrm{e}^{-}$reduced state $\left(\mathrm{H}_{\text {red }} \mathrm{H}^{+}\right)$. The $2 \mathrm{e}^{-}$reduced state $\left(\mathrm{H}_{\text {sred }} \mathrm{H}^{+}\right)$was not observed under our experimental conditions; possibly due to a very low redox potential of the $\mathrm{H}_{\text {red }} \mathrm{H}^{+} \leftrightarrows \mathrm{H}_{\text {sred }} \mathrm{H}^{+}$transition imposed by redox anti-cooperativity between the $\mathrm{H}$-cluster and the reduced F-clusters [45]. This observation implies that the H-cluster does not show 'crossed-over' redox behavior similar to electron-bifurcating flavins. Although according to Zhang et al. redox centers with uncrossed redox potentials can also theoretically act as bifurcating centers under certain conditions [55]. tors from the [FeFe] hydrogenase $C p \mathrm{HydA}$ (PDB: 4XDC [54]), overlaid. $C p H y d A$ was aligned to $\mathrm{Nqo} 3$ in Pymol giving almost perfect alignment of the homologous clusters. HydA contains an additional [2Fe-2S] cluster, for which $C p H y d A$ does not contain a homologous cluster, and $\mathrm{HydB}$ contains an additional two [4Fe-4S] clusters and one $[2 \mathrm{Fe}-2 \mathrm{~S}]$ cluster, for which complex I does not contain homologous clusters

A possible mechanism would be that $\mathrm{H}_{2}$ oxidation at the H-cluster produced a highly reducing $\mathrm{H}_{\text {sred }} \mathrm{H}^{+}$species, which quickly transfers an electron to a nearby iron-sulfur cluster with a very negative redox potential. This would then be followed by downhill electron transfer to the ferredoxinbinding site. The $\mathrm{H}_{\text {red }} \mathrm{H}^{+}$state would then transfer an electron to a different iron-sulfur cluster with a more positive redox potential. We think that this is rather unlikely to be the case in $T m \mathrm{HydABC}$, due to the high sequence similarity between $T m \mathrm{HydA}$ and the structurally characterized [FeFe] hydrogenase from $C$. pasteurianum ( $C p \mathrm{I}$ or $C p \mathrm{HydA}$ ) [4, 54]. $C p H y d A$ contains four accessory iron-sulfur clusters, but only one of them is within electron transfer distance of the H-cluster. Thus, a second proximal iron-sulfur cluster in $T m$ HydA seems unlikely.

We hypothesize, instead, that a complicated arrangement of iron-sulfur clusters, and interactions between them may facilitate a novel elegant electron-bifurcating mechanism. The arrangement of cofactors and subunits in TmHydABC remains unknown. However, the strong homology between $T m \mathrm{HydA}, T m \mathrm{HydB}$, and $T m \mathrm{HydC}$, and the complex I subunits $T t \mathrm{Nqo} 1, T t \mathrm{Nqo} 2$, and $T t \mathrm{Nqo} 3$ from Thermus thermophilus [53], may indicate a similar arrangement of subunits 
and cofactors (Fig. 9). In this arrangement, HydC would be located on one side of $\mathrm{HydB}$, positioning the [2Fe-2S] cluster of HydC close to the FMN cofactor of HydB. Meanwhile, HydA would be located on the opposite side of HydB with the surface exposed [ $2 \mathrm{Fe}-2 \mathrm{~S}]$ cluster of $\mathrm{HydA}$ in electrical contact with the surface exposed [4Fe-4S] cluster of HydB. This arrangement would not be compatible with the previously proposed Fd-binding site being HydC. Instead, Fd would interact with the His-ligated [4Fe-4S] cluster of HydA, as has been proposed for the $C p H y d A$ [56]. With the $\mathrm{H}$-cluster in one direction, the FMN in another direction and the Fd-binding site in a third direction, this arrangement temptingly implicates the trinity of iron-sulfur clusters in HydA as a potential bifurcation site. How, such an arrangement could operate to regulate electron transfer from the $\mathrm{H}$-cluster in one direction or another is unclear, but we speculate that the His-ligated [4Fe-4S] cluster in HydA could play an important role. Further investigations are underway to investigate this possibility. Crucially, our recombinant method for producing $\mathrm{TmHydABC}$ represents the perfect system to perform such in-depth mechanistic studies of the electron-bifurcating mechanism, since it provides an efficient way to produce very high yields of pure protein, as well as making it easy to produce site directed mutations to directly test these ideas.

\section{Conclusion}

In this study, we have developed a method of producing the heterotrimeric electron-bifurcating $[\mathrm{FeFe}]$ hydrogenase from $T$. maritima using recombinant expression and artificial maturation. The time efficiency of the recombinant expression method prevented protein damage and led to high catalytic activity for both $T m \mathrm{Hyd} \mathrm{ABC}$ and $T m \mathrm{HydA}$, outperforming enzymes isolated from the native organism. Our preparation was competent in the electron bifurcation reaction, even in the absence of added FMN. Using FTIR and EPR spectroscopy the three typical states present in all active [FeFe] hydrogenases, i.e., $\mathrm{H}_{\mathrm{ox}}, \mathrm{H}_{\mathrm{red}} \mathrm{H}^{+}$, and $\mathrm{H}_{\text {ox }}-\mathrm{CO}$ could be identified in both $T m \mathrm{HydABC}$ and $T m \mathrm{HydA}$. The unprotonated singly reduced state $\mathrm{H}_{\text {red }}$ as well as the doubly reduced state $\mathrm{H}_{\text {sred }} \mathrm{H}^{+}$(both with a reduced [4Fe-4S]subcluster) were not observed under any condition. This is taken as evidence for a strong electronic coupling between the $\mathrm{H}$-cluster and the F-clusters in the enzyme disfavoring reduction of the cubane subcluster. Our results do not agree with the FMN or the H-cluster as being the site of electron bifurcation. Instead, we hypothesize that the iron-sulfur clusters in the HydA subunit could serve this function. The efficient method presented here for obtaining high quantities of high quality $\mathrm{TmHydABC}$ should pave the road for more protein intensive experiments such as X-ray crystallography, spectroelectrochemistry, and nuclear resonance vibrational spectroscopy, to test our hypothesis, and to help understand the enigmatic mechanism of electron bifurcation in this fascinating $[\mathrm{FeFe}]$ hydrogenase.

Acknowledgements Open access funding provided by Max Planck Society. We thank Yvonne Brandenburger for helping with sample preparation and biochemical characterization and Tabea Mußfeld for synthesis of the complexes. We also thank Norbert Dickmann (MALDI TOF-MS), Dr. Philip Schulze and Sylvia Ruthe, MPI-Kohlenforschung (gas chromatography), and Ingeborg Heise (synthesis) for their assistance. The work was supported by the Max Planck Society and in part by JSPS KAKENHI Grant number 16K21748 (H. O.). J. B. acknowledges the Deutsche Forschungsgemeinschaft Priority Programme "Iron-Sulfur for Life: Cooperative Function of Iron-Sulfur Centers in Assembly, Biosynthesis, Catalysis and Disease" (SPP 1927) Project BI 2198/1-1.

\section{Compliance with ethical standards}

Conflict of interest The authors declare that they have no conflict of interest.

Open Access This article is licensed under a Creative Commons Attribution 4.0 International License, which permits use, sharing, adaptation, distribution and reproduction in any medium or format, as long as you give appropriate credit to the original author(s) and the source, provide a link to the Creative Commons licence, and indicate if changes were made. The images or other third party material in this article are included in the article's Creative Commons licence, unless indicated otherwise in a credit line to the material. If material is not included in the article's Creative Commons licence and your intended use is not permitted by statutory regulation or exceeds the permitted use, you will need to obtain permission directly from the copyright holder. To view a copy of this licence, visit http://creativecommons.org/licenses/by/4.0/.

\section{References}

1. Lubitz W, Ogata H, Rüdiger O, Reijerse E (2014) Chem Rev 114:4081-4148

2. Peters JW, Schut GJ, Boyd ES, Mulder DW, Shepard EM, Broderick JB, King PW, Adams MW (2015) Biochim Biophys Acta 1853:1350-1369

3. Glick BR, Martin WG, Martin SM (1980) Can J Microbiol 26:1214-1223

4. Peters JW, Lanzilotta WN, Lemon BJ, Seefeldt LC (1998) Science 282:1853-1858

5. Nicolet Y, Piras C, Legrand P, Hatchikian CE, Fontecilla-Camps JC (1999) Structure 7:13-23

6. Winkler M, Esselborn J, Happe T (2013) Biochim Biophys Acta 1827:974-985

7. Silakov A, Kamp C, Reijerse E, Happe T, Lubitz W (2009) Biochemistry 48:7780-7786

8. Sommer C, Adamska-Venkatesh A, Pawlak K, Birrell JA, Rüdiger O, Reijerse EJ, Lubitz W (2017) J Am Chem Soc 139:1440-1443

9. Adamska A, Silakov A, Lambertz C, Rüdiger O, Happe T, Reijerse E, Lubitz W (2012) Angew Chem Int Ed Engl 51:11458-11462

10. Mulder DW, Guo Y, Ratzloff MW, King PW (2017) J Am Chem Soc 139:83-86

11. Reijerse EJ, Pham CC, Pelmenschikov V, Gilbert-Wilson R, Adamska-Venkatesh A, Siebel JF, Gee LB, Yoda Y, Tamasaku 
K, Lubitz W, Rauchfuss TB, Cramer SP (2017) J Am Chem Soc 139:4306-4309

12. Greening C, Biswas A, Carere CR, Jackson CJ, Taylor MC, Stott MB, Cook GM, Morales SE (2016) ISME J 10:761-777

13. Sondergaard D, Pedersen CN, Greening C (2016) Sci Rep 6:34212

14. Schut GJ, Adams MW (2009) J Bacteriol 191:4451-4457

15. Huang H, Wang S, Moll J, Thauer RK (2012) J Bacteriol 194:3689-3699

16. Buckel W, Thauer RK (2018) Chem Rev 118:3862-3886

17. Peters JW, Miller AF, Jones AK, King PW, Adams MW (2016) Curr Opin Chem Biol 31:146-152

18. Mitchell P (1975) FEBS Lett 59:137-139

19. Li F, Hinderberger J, Seedorf H, Zhang J, Buckel W, Thauer RK (2008) J Bacteriol 190:843-850

20. Muller V, Chowdhury NP, Basen M (2018) Annu Rev Microbiol 72:331-353

21. Zheng YN, Kahnt J, Kwon IH, Mackie RI, Thauer RK (2014) J Bacteriol 196:3840-3852

22. Buckel W, Thauer RK (2018) Front Microbiol 9:401

23. Buckel W, Thauer RK (2013) Biochim Biophys Acta 1827:94-113

24. Nakamura N, Lin HC, McSweeney CS, Mackie RI, Gaskins HR (2010) Annu Rev Food Sci Technol 1:363-395

25. Wolf PG, Biswas A, Morales SE, Greening C, Gaskins HR (2016) Gut Microbes 7:235-245

26. Verhagen MF, O'Rourke T, Adams MW (1999) Biochim Biophys Acta 1412:212-229

27. Schuchmann K, Muller V (2012) J Biol Chem 287:31165-31171

28. Wang S, Huang H, Kahnt J, Thauer RK (2013) J Bacteriol 195:1267-1275

29. Kpebe A, Benvenuti M, Guendon C, Rebai A, Fernandez V, Le Laz S, Etienne E, Guigliarelli B, Garcia-Molina G, de Lacey AL, Baffert C, Brugna M (2018) Biochim Biophys Acta Bioenerg 1859:1302-1312

30. Greene BL, Schut GJ, Adams MWW, Dyer RB (2017) ACS Catal 7:2145-2150

31. Pan G, Menon AL, Adams MW (2003) J Biol Inorg Chem 8:469-474

32. Verhagen MF, O'Rourke TW, Menon AL, Adams MW (2001) Biochim Biophys Acta 1505:209-219

33. Birrell JA, Laurich C, Reijerse EJ, Ogata H, Lubitz W (2016) Biochemistry 55:4344-4355

34. Esselborn J, Lambertz C, Adamska-Venkatesh A, Simmons T, Berggren G, Noth J, Siebel J, Hemschemeier A, Artero V, Reijerse E, Fontecave M, Lubitz W, Happe T (2013) Nat Chem Biol 9:607-609

35. Birrell JA, Rüdiger O, Reijerse EJ, Lubitz W (2017) Joule 1:61-76

36. Moss D, Nabedryk E, Breton J, Mantele W (1990) Eur J Biochem 187:565-572
37. Stoll S, Schweiger A (2006) J Magn Reson 178:42-55

38. Juszczak A, Aono S, Adams MW (1991) J Biol Chem 266:13834-13841

39. Kertess L, Wittkamp F, Sommer C, Esselborn J, Rüdiger O, Reijerse EJ, Hofmann E, Lubitz W, Winkler M, Happe T, Apfel UP (2017) Dalton Trans 46:16947-16958

40. Wang S, Huang H, Kahnt J, Mueller AP, Kopke M, Thauer RK (2013) J Bacteriol 195:4373-4386

41. Lemon BJ, Peters JW (1999) Biochemistry 38:12969-12973

42. Pierik AJ, Hulstein M, Hagen WR, Albracht SP (1998) Eur J Biochem 258:572-578

43. Lubitz W, Reijerse E, van Gastel M (2007) Chem Rev 107:4331-4365

44. Roseboom W, De Lacey AL, Fernandez VM, Hatchikian EC, Albracht SP (2006) J Biol Inorg Chem 11:102-118

45. Rodríguez-Maciá P, Pawlak K, Rüdiger O, Reijerse EJ, Lubitz W, Birrell JA (2017) J Am Chem Soc 139:15122-15134

46. Ratzloff MW, Artz JH, Mulder DW, Collins RT, Furtak TE, King PW (2018) J Am Chem Soc 140:7623-7628

47. Smith ET, Adams MW (1994) Biochim Biophys Acta 1206:105-112

48. Siebel JF, Adamska-Venkatesh A, Weber K, Rumpel S, Reijerse E, Lubitz W (2015) Biochemistry 54:1474-1483

49. Adamska-Venkatesh A, Krawietz D, Siebel J, Weber K, Happe T, Reijerse E, Lubitz W (2014) J Am Chem Soc 136:11339-11346

50. Poudel S, Tokmina-Lukaszewska M, Colman DR, Refai M, Schut GJ, King PW, Maness PC, Adams MW, Peters JW, Bothner B, Boyd ES (2016) Biochim Biophys Acta 1860:1910-1921

51. Peters JW, Beratan DN, Schut GJ, Adams MWW (2018) Chem Commun 54:4091-4099

52. Nitschke W, Russell MJ (2012) BioEssays 34:106-109

53. Baradaran R, Berrisford JM, Minhas GS, Sazanov LA (2013) Nature 494:443-448

54. Esselborn J, Muraki N, Klein K, Engelbrecht V, Metzler-Nolte N, Apfel UP, Hofmann E, Kurisu G, Happe T (2016) Chem Sci 7:959-968

55. Zhang P, Yuly JL, Lubner CE, Mulder DW, King PW, Peters JW, Beratan DN (2017) Acc Chem Res 50:2410-2417

56. Artz JH, Mulder DW, Ratzloff MW, Lubner CE, Zadvornyy OA, LeVan AX, Williams SG, Adams MWW, Jones AK, King PW, Peters JW (2017) J Am Chem Soc 139:9544-9550

Publisher's Note Springer Nature remains neutral with regard to jurisdictional claims in published maps and institutional affiliations.

\section{Affiliations}

\section{Nipa Chongdar ${ }^{1} \cdot$ Krzysztof Pawlak $^{1}$ - Olaf Rüdiger ${ }^{1} \cdot$ Edward J. Reijerse $^{1} \cdot$ Patricia Rodríguez-Maciá $^{1}$. Wolfgang Lubitz ${ }^{1}$. James A. Birrell ${ }^{1}$. Hideaki Ogata ${ }^{1,2}$}

Nipa Chongdar

nipa.chongdar@cec.mpg.de

James A. Birrell

james.birrell@cec.mpg.de

Hideaki Ogata

hideaki.ogata@pop.lowtem.hokudai.ac.jp
1 Max Planck Institute for Chemical Energy Conversion, Stiftstrasse 34-36, 45470 Mülheim an der Ruhr, Germany

2 Institute of Low Temperature Science, Hokkaido University, Kita-19, Nishi-8, Kita-ku, Sapporo 060-0819, Japan 